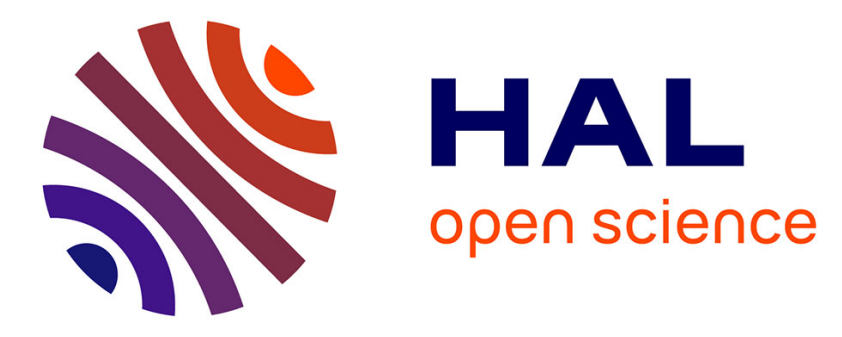

\title{
Use of palmitoleic acid and its oxidation products for monitoring the degradation of ice algae in Arctic waters and bottom sediments
}

\author{
Jean-Francois Rontani, Remi Amiraux, Catherine Lalande, Marcel Babin, \\ Hak-Ryul Kim, Simon Belt
}

\section{To cite this version:}

Jean-Francois Rontani, Remi Amiraux, Catherine Lalande, Marcel Babin, Hak-Ryul Kim, et al.. Use of palmitoleic acid and its oxidation products for monitoring the degradation of ice algae in Arctic waters and bottom sediments. Organic Geochemistry, 2018, 124, pp.88-102. 10.1016/j.orggeochem.2018.06.002 . hal-02024257

\section{HAL Id: hal-02024257 \\ https://hal-amu.archives-ouvertes.fr/hal-02024257}

Submitted on 25 Feb 2019

HAL is a multi-disciplinary open access archive for the deposit and dissemination of scientific research documents, whether they are published or not. The documents may come from teaching and research institutions in France or abroad, or from public or private research centers.
L'archive ouverte pluridisciplinaire HAL, est destinée au dépôt et à la diffusion de documents scientifiques de niveau recherche, publiés ou non, émanant des établissements d'enseignement et de recherche français ou étrangers, des laboratoires publics ou privés.

\section{(ㄷ)(i)}

Distributed under a Creative Commons Attribution| 4.0 International License 


\title{
Use of palmitoleic acid and its oxidation products for monitoring the degradation of ice algae in Arctic waters and bottom sediments
}

\author{
Jean-François Rontani ${ }^{\mathrm{a}, *}$, Rémi Amiraux ${ }^{\mathrm{a}}$, Catherine Lalande ${ }^{\mathrm{b}}$, Marcel Babin ${ }^{\mathrm{b}}$, Hak-Ryul Kimc ${ }^{\mathrm{c}}$, \\ Simon T. Belt ${ }^{\mathrm{d}}$ \\ ${ }^{a}$ Aix Marseille Univ, Université de Toulon, CNRS/INSU/IRD, Mediterranean Institute of Oceanography (MIO) UM 110, 13288 Marseille, France \\ ${ }^{\mathrm{b}}$ Takuvik Joint Laboratory, Département de Biologie/Pavillon Alexandre-Vachon, Université Laval, Québec, Québec G1V 0A6, Canada \\ ${ }^{\mathrm{c}}$ School of Food Science and Biotechnology, Kyungpook National University, Daegu 41566, Republic of Korea \\ ${ }^{\mathrm{d}}$ Biogeochemistry Research Centre, School of Geography, Earth and Environmental Sciences, University of Plymouth, Drake Circus, Plymouth, Devon PL4 8AA, UK
}

Keywords:

Palmitoleic acid

Sympagic algae

Arctic

Biotic and abiotic degradation

Sea ice

Sinking particles

Superficial bottom sediments

\begin{abstract}
A B S T R A C T
Degradation of palmitoleic acid $\left(\mathrm{C}_{16: 1 \omega 7}\right)$, the main fatty acid component of sea ice-associated (sympagic) diatoms, was monitored in Arctic sea ice at the beginning of ice melting and in the underlying sinking particles and superficial bottom sediments. In sea ice, degradation of sympagic algae involved biotic oxidation induced by 10S-DOX-like lipoxygenase of unknown salinity-stressed attached bacteria, while photo- and autoxidation were limited. In the water column, strong hydratase and $Z / E$ isomerase activity were observed. Hydration of unsaturated fatty acids seems to be a detoxification strategy, which is essential for bacterial survival when associated with free fatty acid-rich environments such as ice algae. In contrast, $Z / E$ isomerisation of palmitoleic acid was attributed to the release of $\mathrm{Fe}^{2+}$ ions during radicalinduced damage of the active site of the bacterial 10S-DOX-like lipoxygenase and $Z / E$ isomerases. Due to the poor physiological state of their attached bacteria resulting from salinity stress in brine channels or toxicity of free ice algae fatty acids, sympagic algae appeared to be only very weakly biotically degraded within the water column. In bottom sediments, free radicals resulting from 10S-DOX-like lipoxygenase activity induced a strong autoxidation of the ice algal material. The presence in bottom sediments of a significant proportion of oxidation products resulting from 10S-DOX-like lipoxygenase activity attested to the strong contribution of sea ice-derived OM released during the early stages of ice melt prior to deposition in the sediments. However, on the basis of the highest fatty acid photooxidation state observed in these sediments, an additional contribution of highly photooxidized material (ice algal material released at the end of ice melting or open water phytoplankton) seems likely. The degradation of hydroperoxides, resulting from biotic and abiotic degradation of palmitoleic acid, appeared to involve: (i) homolytic cleavage of the peroxyl group affording the corresponding hydroxy- and oxoacids, (ii) reduction to the corresponding hydroxyacids by peroxygenases, (iii) heterolytic proton-catalysed cleavage and (iv) conversion to allylic 1,4-diols by diol synthases and hydroperoxide isomerases.
\end{abstract}

\section{Introduction}

The thinning and retreat of Arctic sea ice, which is one of the most striking consequences of recent climate change, will likely have a significant impact on Arctic ecosystem functioning in the future (Wassmann et al., 2011). Continued changes in the polar seas and sea ice retreat will also affect marine biogeochemical cycles, with possibly important feedbacks to the climate and marine ecosystems (Arzel et al., 2006).

\footnotetext{
* Corresponding author.

E-mail address: jean-francois.rontani@mio.osupytheas.fr (J.-F. Rontani).
}

Reduction of sea ice in the Arctic under the effect of global warming should significantly alter the relative fluxes of phytoplankton and ice algae to the seafloor (Carroll and Carroll, 2003). A climate-change-mediated shift in primary producers would thus impact the structure and function of the sea floor community, which is strongly dependent upon the deposition of organic material from the overlying water column for its energy requirements (McMahon et al., 2006). Moreover, under the effect of global warming the carbon sink potential of ice algae (resulting from their strong aggregation and the stress state of their associated bacteria, should be gradually replaced by the carbon source potential of open water phytoplankton (weakly aggregated and mineralized before the bottom) (Amiraux et al., 2017). 
Determining the fate of sympagic (ice-associated) derived particulate organic matter (POM) following its release from sea ice during spring melting is thus an important research objective (Tedesco and Fettweis, 2012), but partitioning processes such as growth of the water column phytoplankton community, grazing, remineralization and export is complicated and currently not well constrained. The strong pulse of particulate OM released into the water column during ice melt provides essential energy at the base of the Arctic food web (Michel et al., 1996; Lizotte, 2001), although some sinks to the seafloor (Riebesell et al., 1991; Fortier et al., 2002; Renaud et al., 2007). Ultimately, the material that is not grazed or re-mineralized during its descent through the water column, can feed the benthos (Boetius et al., 2013) or be stored in sediments.

In practice, many factors influence the quantity and the quality of the sympagic OM reaching the seafloor. These include the physical characteristics of the water column, including water depth and whether it is well mixed or stratified, the latter being a particular feature of Arctic waters due to the lower salinity caused by ice melt in spring and freshwater runoff. In addition, the fate of sympagic OM is influenced by physiological, morphological and ecological factors such as cell agglomeration and grazing by under-ice and water column heterotrophs (Vancoppenolle et al., 2013). A particular feature of sea ice biota is their ability to produce large quantities of so-called extracellular polymeric substances (EPS), which serve as a cryoprotectant within the ice matrix. Indeed, EPS concentrations in Arctic sea ice are typically at least an order of magnitude higher than for under-ice and open water environments (Krembs and Engel, 2001; Meiners et al., 2003), which promotes aggregation of sympagic algae and thus enhances export efficiency to the seafloor. The contribution of ice algae to the underlying sediments also depends strongly on the remineralization potential of their associated bacteria. Recently, it was observed that during the early stage of ice melting, hypersaline conditions in brine channels strongly impact the bacterial community associated with ice algae (Amiraux et al., 2017). The resulting poor physiological state of these bacteria should likely contribute to the preservation of the algal material prior to deposition on the ocean bottom.

Lipid biomarkers, although only representing a relatively minor fraction of the total OM, can convey important information on the source (terrigenous, marine or bacterial) and degradation state of $\mathrm{OM}$, and their distributions are often more informative than bulk parameters such as total organic carbon (Saliot et al., 2002). Furthermore, the oxidation products of monounsaturated fatty acids appear to be especially useful for differentiating the involvement of photo- and autoxidative degradation processes in suspended and sinking particulate matter and bottom sediment samples (for a review see Rontani, 2012). More recently, analysis of these compounds provided evidence of lipoxygenase-induced degradation in suspended (Galeron et al., 2018) and sinking (Amiraux et al., 2017) particles.

Since the integrity of the strong pulse of particulate organic matter (POM) released during Arctic ice melt remains largely unexamined, we monitored biotic and abiotic degradation processes in ice algae released from melting Arctic sea ice and their transfer to the ocean bottom using pathway-specific degradation tracer products of palmitoleic acid $\left(C_{16: 1 \omega 7}\right)$. Indeed, although present in several bacteria (e.g., de Carvalho and Caramujo, 2014), palmitoleic acid is also the major fatty acid of diatoms (Fahl and Kattner, 1993; Leu et al., 2010), which strongly dominate the biomass in sea ice.

\section{Experimental}

\subsection{Sampling}

Ice cores, sinking particles and superficial bottom sediments were collected during the spring of 2015 at a landfast ice station

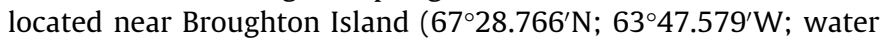
column depth: $379 \mathrm{~m}$ ) north of Davis Strait, Canada (GreenEdge ice camp 2015). Sea ice and sinking particles were sampled during the early stage of ice melt (Amiraux et al., 2017). An ice core was collected on 4 June 2015 using a $9 \mathrm{~cm}$ internal diameter Mark II coring system (Kovacs Enterprises) and sliced in the field. The bottom $1 \mathrm{~cm}$ slice, which corresponds to the ice-ocean interface and contains the largest amount of ice algae, was allowed to melt in filtered seawater (FSW; $0.2 \mu \mathrm{m}$ ) using at least 2 parts FSW for 1 part of ice in order to limit osmotic stress and filtered (Whatman GF/F $47 \mathrm{~mm}$ ). Short-term sediments traps were deployed to collect sinking particles over $48 \mathrm{~h}$ at $2 \mathrm{~m}$ and $25 \mathrm{~m}$ with two mooring lines. Sediment traps were made of polyvinyl chloride (PVC) and had an aperture diameter of $15 \mathrm{~cm}$. The recovery of the samples analyzed in the present study took place on 8-10 June 2015 (at the time of highest flux of sinking material measured during this time series, Lalande, unpublished data). A sub-sample for lipid analysis (corresponding to $4.5 \%$ of the total sample) was filtered onto Whatman GF/F $47 \mathrm{~mm}$ filter. Superficial bottom sediment samples (ca. $0-1 \mathrm{~cm}$ ) were also collected using box corers at the same sampling location on board the CCGS Amundsen in October 2015 as part of the GreenEdge project. All the samples were kept frozen $\left(-20^{\circ} \mathrm{C}\right)$ until analysis.

\subsection{Treatment}

Samples (filters or sediments) were reduced with excess $\mathrm{NaBH}_{4}$ or $\mathrm{NaBD}_{4}$ after addition of $\mathrm{MeOH}(25 \mathrm{ml} ; 30 \mathrm{~min})$ to reduce labile hydroperoxides to alcohols which are more amenable to analysis using gas chromatography-mass spectrometry. Water $(25 \mathrm{ml})$ and $\mathrm{KOH}(2.8 \mathrm{~g})$ were then added and the resulting mixture saponified by refluxing (2h). After cooling, the mixture was acidified $(\mathrm{HCl}$, $2 \mathrm{~N})$ to $\mathrm{pH} 1$ and extracted with dichloromethane (DCM; $3 \times 20$ $\mathrm{ml}$ ). The combined DCM extracts were dried over anhydrous $\mathrm{Na}_{2}-$ $\mathrm{SO}_{4}$, filtered and concentrated via rotary evaporation at $40^{\circ} \mathrm{C}$ to give total lipid extracts (TLEs). TLEs were derivatized by dissolving them in $300 \mu \mathrm{l}$ of pyridine/bis(trimethylsilyl)trifluoroacetamide (BSTFA; Supelco; $2: 1, \mathrm{v}: \mathrm{v})$ and silylated $\left(50{ }^{\circ} \mathrm{C}, 1 \mathrm{~h}\right)$. After evaporation to dryness under a stream of $\mathrm{N}_{2}$, the derivatized residue was dissolved in ethyl acetate/BSTFA (to avoid desilylation) and analyzed using gas chromatography-electron ionization quadrupole time of flight mass spectrometry (GC-QTOFMS).

A different treatment was employed to estimate the relative proportions of hydroperoxides and their ketonic and alcoholic degradation products. Subsamples were extracted three times with chloroform-MeOH- $\mathrm{H}_{2} \mathrm{O}$ (1:2:0.8, v:v:v) using ultrasonication. The supernatant was separated by centrifugation at $3500 \mathrm{~g}$ for $9 \mathrm{~min}$. To initiate phase separation, purified $\mathrm{H}_{2} \mathrm{O}$ was added to the combined extracts. The upper aqueous phase was extracted three times with DCM and the combined organic phase and DCM extracts were filtered and the solvent removed via rotary evaporation. The residue obtained after extraction was dissolved in $4 \mathrm{ml}$ of DCM and separated in two equal subsamples. After evaporation of the solvent, degradation products were obtained for the first subsample after acetylation, which induced conversion of hydroperoxides to the corresponding ketones (Mihara and Tateba, 1986), and 
saponification. The second subsample was reduced with $\mathrm{NaBD}_{4}$ and saponified. Comparison of the amounts of alcohols present after acetylation and $\mathrm{NaBD}_{4}$ reduction made it possible to estimate the amount of hydroperoxides and alcohols present in the samples, while deuterium labeling after $\mathrm{NaBD}_{4}$ reduction allowed us to estimate the proportion of ketones present in the samples (Marchand and Rontani, 2003).

Acetylation was carried out in $300 \mu \mathrm{l}$ of a mixture of pyridine and acetic anhydride (2:1, v:v), which was allowed to react at 50 ${ }^{\circ} \mathrm{C}$ overnight and then evaporated to dryness under a stream of $\mathrm{N}_{2}$.

\subsection{GC-QTOFMS}

Oxidation products of palmitoleic acid were identified and quantified using an Agilent 7890B/7200A GC-QTOF System (Agilent Technologies, Parc Technopolis - ZA Courtaboeuf, Les Ulis, France). A cross-linked 5\% phenyl-methylpolysiloxane (Macherey Nagel; Optima 5-MS Accent) column $(30 \mathrm{~m} \times 0.25 \mathrm{~mm}, 0.25 \mu \mathrm{m}$ film thickness) was employed. Analysis was performed with an injector operating in pulsed splitless mode at $280^{\circ} \mathrm{C}$ and the oven temperature programmed from $70^{\circ} \mathrm{C}$ to $130^{\circ} \mathrm{C}$ at $20^{\circ} \mathrm{C} / \mathrm{min}$, then to $250{ }^{\circ} \mathrm{C}$ at $5{ }^{\circ} \mathrm{C} / \mathrm{min}$ and then to $300^{\circ} \mathrm{C}$ at $3^{\circ} \mathrm{C} / \mathrm{min}$. The carrier gas (He) was maintained at $0.69 \times 10^{5} \mathrm{~Pa}$ until the end of the temperature program. Instrument temperatures were $300{ }^{\circ} \mathrm{C}$ for the transfer line and $230^{\circ} \mathrm{C}$ for the ion source. Accurate mass spectra were obtained across the range $m / z 50-700$ at $4 \mathrm{GHz}$. The QTOFMS instrument provided a typical resolution ranging from 8009 to 12,252 from $\mathrm{m} / \mathrm{z} 68.9955$ to 501.9706. Perfluorotributylamine (PFTBA) was utilized for daily MS calibration. Compounds were identified by comparison of their TOF mass spectra, accurate masses and retention times with those of standards, either purchased or synthesized in the laboratory (see following Section). Quantification of each compound involved extraction of specific accurate fragment ions, peak integration and determination of individual response factors using external standards.

\subsection{Standard compounds}

(8-11)-Hydroperoxyhexadec-(8-10)-enoic acids ( $Z$ and $E$ ) acids (1-6) (see Appendix A) were produced by $\mathrm{Fe}^{2+}$ /ascorbate induced autoxidation (Loidl-Stahlhofen and Spiteller, 1994) of palmitoleic acid. Subsequent reduction of these different hydroperoxides in methanol with excess $\mathrm{NaBH}_{4}$ afforded the corresponding hydroxyacids. Hydrogenation of these hydroxyacids was carried out in methanol with $\mathrm{Pd} / \mathrm{CaCO}_{3}$ as catalyst. Treatment of palmitoleic acid with meta-chloroperoxybenzoic acid in dry methylene chloride yielded 9,10-epoxyhexadecanoic acid (20). Hydrolysis of this epoxide in $\mathrm{HCl}(2 \mathrm{~N})$ afforded the corresponding chlorohydrins, while methanolysis yielded the corresponding methoxyhydrins. Threo and erythro 9,10-dihydroxyhexadecanoic acids (17) were respectively obtained after stereospecific oxidation of the double bond of palmitelaidic (the trans isomer of palmitoleic acid: hexadec- 9 (E)-enoic acid) and palmitoleic acids with $\mathrm{OsO}_{4}$ in pyridinedioxane (McCloskey and McClelland, 1965). Threo and erythro 8,11-dihydroxyoctadec-9( $E$ and $Z$ )-enoic acids (22 and 23 ) were produced in low yield (5-10\%) by oxidation of palmitoleic acid with $\mathrm{SeO}_{2}$-t-butylhydroperoxide (Knothe et al., 1994). A standard of threo 7,10-dihydroxyoctadec-8(E)-enoic acid (42) containing $10 \%$ of threo 7,10-dihydroxyhexadec-8(E)-enoic acid (21) previously produced by Pseudomonas aeruginosa PR3 (Suh et al., 2011) was obtained from Dr. H.R. Kim (School of Food Science and Biotechnology, Kyungpook National University, Daegu, Korea).

\subsection{Estimation of autoxidative, photooxidative and 10S-DOX degradation}

The role played by autoxidation in the degradation of palmitoleic acid was estimated by considering the proportion of its specific Z-oxidation products (Frankel, 1998) and the water temperature according to the approach previously described by Marchand and Rontani (2001). After subtraction of the amounts of oxidation products of autoxidative origin, it remained to determine the relative parts played by photooxidative and enzymatic processes in the degradation. Taking into account the production of equal amounts of $9-E(\mathbf{8})$ and $10-E(\mathbf{9})$ oxidation products during the photooxidation of the $\Delta^{9}$ monounsaturated fatty acids (Frankel, 1998) and their specific allylic rearrangement to $11-E$ (5) and 8-E (6) isomers, respectively (Porter et al., 1995), the contribution of photooxidative degradation was estimated to be $2 \times$ $(9-E+11-E)$. Concerning 10S-DOX degradation, this was obtained from the difference between $(10-E+8-E)$ and $(9-E+11-E)$ oxidation products, to which was added the amount of 7,10dihydroxyhexadec-8(E)-enoic acid (21) formed (Galeron et al., 2018).

\section{Results}

Significant proportions (increasing from $3.5 \%$ relative to the residual parent palmitoleic acid in sea ice to $25 \%$ in sediments) of $\mathrm{C}_{16}$ isomeric allylic hydroperoxyacids (11-hydroperoxyhexadec9(E)-enoic (1), 9-hydroperoxyhexadec-10 $(E)$-enoic (2), 10-hydroperoxyhexadec-8(E)-enoic (3), 8-hydroperoxyhexadec-9(E)-enoic (4), 11-hydroperoxyhexadec-9(Z)-enoic (5) and 8-hydroperoxyhexadec-9(Z)-enoic (6) acids) (see Appendix A) and of the corresponding hydroxy- and oxoacids could be detected in the different samples investigated (Table 1). After $\mathrm{NaBH}_{4}$ reduction, the mixtures of the corresponding isomeric hydroxyacids appeared to be strongly dominated by 10 -hydroxyhexadec-8(E)-enoic acid $(\mathbf{9})$ in sea ice (Fig. 1a) and by 10-hydroxyhexadec-8(E)-enoic (9) and 8-hydroxyhexadec-9(E)-enoic (10) acids in sinking particles (Fig. 1b). This dominance relative to the other isomers was less apparent in superficial bottom sediments (Fig. 1c).

Saturated hydroxyacids (9-hydroxyhexadecanoic (13) and 10hydroxyhexadecanoic (14) acids), methoxyhydrins (9-hydroxy10-methoxyhexadecanoic (15) and 9-methoxy-10-hydroxyhexadecanoic (16) acids), diols (diastereoisomeric 9,10-dihydroxyhexadecanoic acids (17)) and chlorohydrins (9-hydroxy-10chlorohexadecanoic (18) and 9-chloro-10-hydroxyhexadecanoic (19) acids), all derived from the degradation of ( $Z$ and $E$ ) 9,10epoxyhexadecanoic acids (20) during the sample treatment (Fig. 2; Marchand and Rontani, 2001), could be also detected (Fig. 1). $\mathrm{NaBH}_{4}$ reduction of mid-chain epoxides is generally slow and not regioselective (Zabeti et al., 2010); the higher proportions of 10-hydroxyhexadecanoic acid (14) relative to 9-hydroxyhexadecanoic acid (13) observed (Fig. 1) thus suggest the involvement of an additional source of the 10-isomer. The concentration of epoxides was thus estimated on the basis of their degradation product concentrations according to the following equation: ( $2 \times$ [9-hydroxyhexadecanoic acid] + [methoxyhydrins] $+[$ diols] + [chlorohydrins]). Interestingly, their percentage relative to the sum of the parent palmitoleic acid and its degradation products increased from $1 \%$ in sea ice to $17 \%$ in superficial bottom sediments.

Isomeric allylic dihydroxyhexadecenoic acids could be also detected (Table 1, Fig. 3). Threo 7,10-dihydroxyhexadec-8(E)enoic (21), threo and erythro 8,11-dihydroxyhexadec-9(E)-enoic (22) and erythro 8,11-dihydroxyhexadec-9(Z)-enoic acids (23) 
Table 1

Concentration of palmitoleic acid and its degradation products in sea ice, sinking particle and surficial bottom sediment samples collected in Davis Strait.

\begin{tabular}{|c|c|c|c|c|}
\hline Compounds & $\begin{array}{l}\text { Sea ice } \\
(0-1 \mathrm{~cm}) \\
\left(\mathrm{ng} \mathrm{ml}^{-1}\right)\end{array}$ & $\begin{array}{l}\text { Sinking particles (trap } 2 \mathrm{~m} \text { ) } \\
\left(\mu \mathrm{g} \mathrm{m}^{-1} \mathrm{~d}^{-1}\right)\end{array}$ & $\begin{array}{l}\text { Sinking particles (trap } 25 \mathrm{~m}) \\
\left(\mu \mathrm{g} \mathrm{m}^{-1} \mathrm{~d}^{-1}\right)\end{array}$ & $\begin{array}{l}\text { Surface sediment }(0-1 \mathrm{~cm}) \\
\left(\mu \mathrm{g} \mathrm{g}^{-1}\right)\end{array}$ \\
\hline Hexadec-9(Z)-enoic acid (Palmitoleic acid) & 10,105 & 345 & 437 & 7.5 \\
\hline (8-11)-Hydroperoxyhexadec-(8-10)( $Z$ and $E)$-enoic acids (1-6) & 104.5 & 3.3 & 3.2 & 1.1 \\
\hline (8-11)-Hydroxyhexadec-(8-10)(Z and $E)$-enoic acids (7-12) & 137.8 & 4.4 & 4.3 & 1.0 \\
\hline$(8-11)$-Oxohexadec-(8-10)(Z and $E)$-enoic acids (36-41) & 130.3 & 4.1 & 4.0 & 1.8 \\
\hline 10-Hydroxyhexadecanoic acid (14) & 19.4 & 2.2 & 2.8 & 0.6 \\
\hline 10-Oxohexadecanoic acid (35) & 2.1 & 0.2 & 0.3 & 0.1 \\
\hline $9,10(Z$ and $E)$-Epoxyhexadecanoic $\operatorname{acid}^{1}(\mathbf{2 0})$ & 109.2 & 3.4 & 3.6 & 2.7 \\
\hline 7,10-Dihydroxyhexadec-8(E)-enoic acid (threo) (21) & 1.8 & 0.5 & 0.3 & 0.2 \\
\hline 7,10-Dihydroxyhexadec-8(E)-enoic acid (erythro) $(\mathbf{2 1})$ & 1.5 & 0.3 & 0.3 & 0.1 \\
\hline 8,11-Dihydroxyhexadec-9(Z)-enoic acid (threo or erythro) (23) & 2.5 & 0.8 & 0.3 & 0.2 \\
\hline 8,11-Dihydroxyhexadec-9(E)-enoic acid (threo) (22) & 1.9 & 0.3 & 0.2 & 0.1 \\
\hline 8,11-Dihydroxyhexadec-9(E)-enoic acid (erythro) (22) & 0.8 & 0.3 & 0.2 & 0.1 \\
\hline 9,12-Dihydroxyhexadec-10(E)-enoic acid (threo or erythro) (24) & 1.9 & 0.1 & 0.1 & 0.3 \\
\hline Ratio hexadec- $9(E)$-enoic acid/hexadec- $9(Z)$-enoic acid & 0.03 & 0.04 & 0.22 & 0.27 \\
\hline
\end{tabular}

${ }^{1}$ Sum of epoxide degradation products (alcohols + diols + chlorohydrins + methoxyhydrins) (Fig. 2).

could be formally identified by comparison of their accurate mass spectra (Fig. 4a and c) and retention times with those of reference compounds. The compound eluting just after threo 7,10dihydroxyhexadec-8(E)-enoic acids (21) (Fig. 3), and exhibiting exactly the same mass spectrum, was attributed to the erythro diastereoisomer. Indeed, it was observed previously that threo and erythro diastereoisomers of TMS derivatives of dihydroxyhexadecanoic acids eluted on an apolar column in the same order (Hansel and Evershed, 2009). Erythro 9,12-dihydroxyhexadec-10 (E)-enoic acids (24) were tentatively identified on the basis of the accurate mass fragmentations of their trimethylsilyl derivatives (Fig. 4b) and the abundance of the $m / z 147$ peak in their mass spectra, which is similar to those of the other $E$ isomers (Fig. 4a and c). Indeed, this fragment ion, which arises from interaction between two TMS groups, is always more intense in the EI mass spectrum of the $Z$ isomer compared to its $E$ counterpart (Zaikin and Halket, 2009). The percentage of these isomeric dihydroxyhexadecenoic acids increased from $0.1 \%$ in sea ice to $6 \%$ in superficial bottom sediments.

A significant increase of the proportion of hexadec- $9(E)$-enoic (palmitelaidic) acid relative to palmitoleic acid was apparent in the deeper sediment trap and in superficial bottom sediments (Table 1).

\section{Discussion}

\subsection{Degradation of palmitoleic acid in sea ice $(0-1 \mathrm{~cm})$}

Type II photosensitized oxidation (i.e. involving singlet oxygen) of palmitoleic acid produces equal proportions of isomeric 9- and 10-hydroperoxides (2 and $\mathbf{3}$ ) with an allylic $E$ double bond (Frankel, 1998), which can subsequently undergo highly stereoselective radical allylic rearrangement to $11-E$ and $8-E$ hydroperoxides (1 and 4), respectively (Fig. 5; Porter et al., 1995). In contrast, autoxidation (i.e. free radical induced oxidation) affords a mixture of $9-E(\mathbf{2}), 10-E(\mathbf{3}), 11-E(\mathbf{1}), 11-Z(\mathbf{5}), 8-E(\mathbf{4})$, and $8-Z$ (6) hydroperoxides, also exhibiting equal proportions of the major 9-E (2) and 10-E (3) isomers (Fig. 5; Frankel, 1998). The strong predominance of the 10-E hydroxyacid (9) observed in sea ice after $\mathrm{NaBH}_{4}$ reduction (Fig. 1) is thus very surprising. Similar profiles of palmitoleic acid oxidation products were observed previously in other sea ice samples (Amiraux et al., submitted for publication) and in sinking particles underlying melting sea ice (Amiraux et al., 2017), also in the Canadian Arctic, and attributed to the involvement of a specific bacterial enzymatic process under the hypersaline conditions found in brine channels. Indeed, a 10SDOX-like lipoxygenase able to convert palmitoleic acid to $10(S)$ hydroperoxyhexadec-8(E)-enoic acid (3) was previously isolated from Pseudomonas aeruginosa 42A2 (Guerrero et al., 1997; Busquets et al., 2004). Palmitoleic acid is a major constituent of numerous bacteria (Oliver and Colwell, 1973; Viso and Marty, 1993), although it is also the predominant fatty acid in sea ice diatoms (Fahl and Kattner, 1993), which make up the major part of the biomass in sea ice. The presence of high proportions of 10hydroperoxyhexadec-8(E)-enoic acid (3) in sea ice was thus attributed to the degradation of ice algae by some of their attached bacteria (Amiraux et al., 2017), consistent with the autonomous action of prokaryotic lipoxygenases on the membrane phospholipids of their eukaryotic cell hosts (Vance et al., 2004; Garreta et al., 2013).

The involvement of 10S-DOX-like lipoxygenase enzymatic activity in the sea ice sample investigated herein is further supported by the detection of threo 7,10-dihydroxyhexadec-8(E)enoic acid (21) (Table 1, Fig. 3) formed from the specific action of $7 S, 10 S$-hydroperoxide diol synthase (linked to the 10S-DOX-like lipoxygenase enzymatic activity) (Fig. 5; Estupiñán et al., 2014, 2015 ) on $10(S)$-hydroperoxyhexadec-8(E)-enoic acid (3). This enzyme appeared to be inactive towards reaction with 9hydroperoxyhexadec-10 $(E)$-enoic acid (2), since there was an absence of threo 9,12-dihydroxyhexadec-10(E)-enoic acid (24) (Fig. 5), although it converted 12-hydroperoxyoctadec-10(E)enoic acid (25) (arising from vaccenic acid oxidation) to threo 9,12-dihydroxyoctadec-10(E)-enoic acid (31) (Table 2). These contrasting results suggest that the diol synthase present in the Arctic bacteria is only active on allylic hydroperoxides allowing the formation of a diol between the carboxyl and the peroxyl groups and not on those where the diol is formed between the methyl and the peroxyl groups (Table 3). Consequently, the formation of threo 8,11-dihydroxyoctadec-9(E)-enoic acid (22) (Fig. 5) likely results from the reaction of this enzyme with 11hydroperoxyhexadec-9(E)-enoic acid (1) rather than with 8hydroperoxyhexadec-9(E)-enoic acid (4) (Table 2).

The relatively low proportions of $9 E$ - and $11 E$-hydroxyacids (Fig. 1a) is consistent with the low efficiency of Type II photooxidation processes on ice algae, attributed previously to the good physiological state of algae at the time of sampling (Amiraux et al., 2017). Autoxidation also appeared to be limited in the sea ice sample as shown by the low amounts of specific $8 Z$ - and $11 Z$ hydroxyacids (Fig. 1a). 

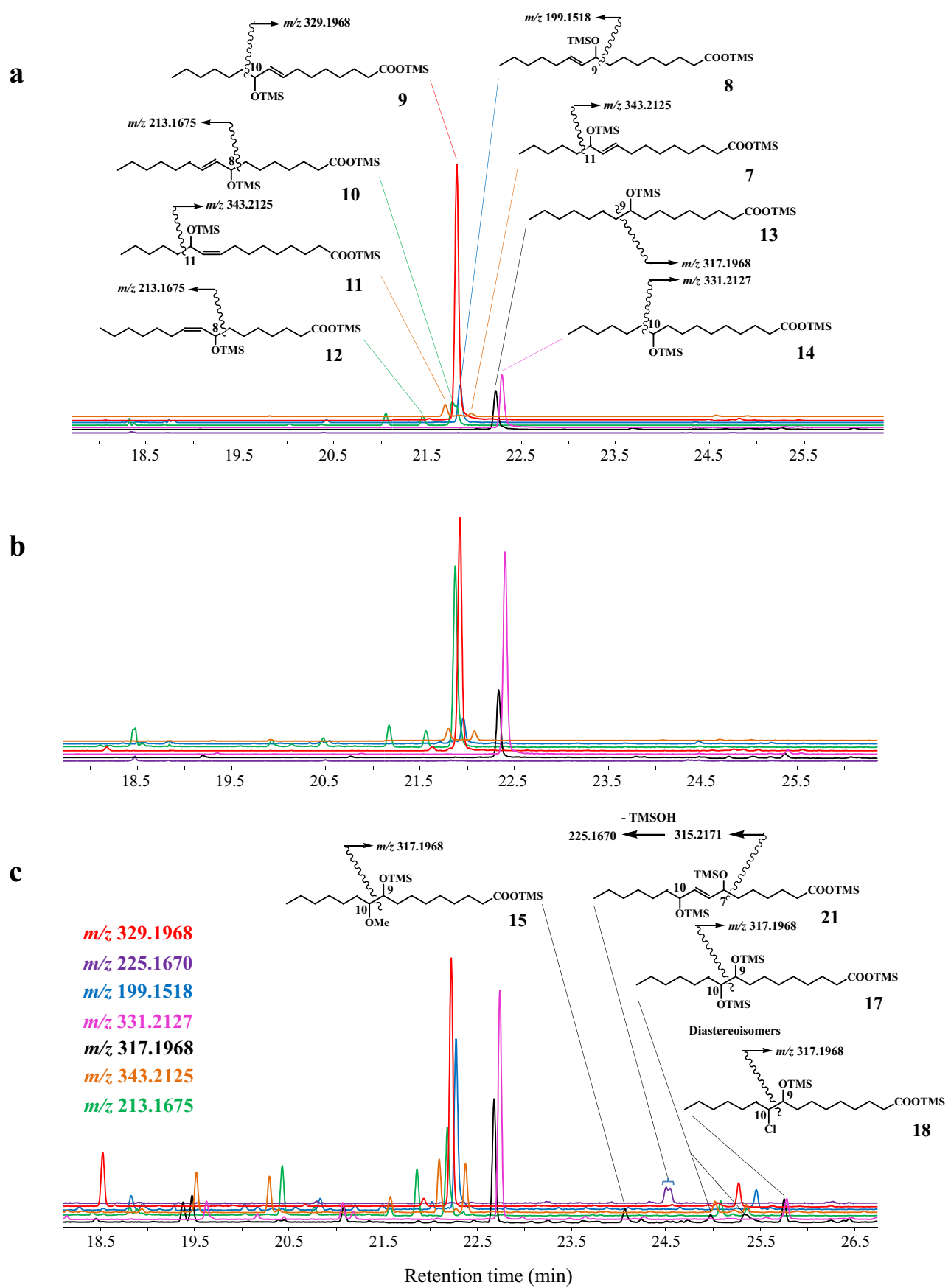

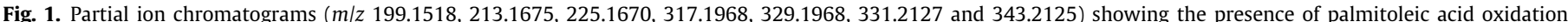
products in sea ice $(0-1 \mathrm{~cm})(\mathrm{a})$, sediment trap $(25 \mathrm{~m})(\mathrm{b})$ and superficial bottom sediments $(0-1 \mathrm{~cm})(\mathrm{c})$.

The degradation of all these labile isomeric hydroperoxyacids arising from photooxidative, autoxidative and enzymatic processes in sea ice involves: (i) homolytic cleavage of the peroxyl group affording the corresponding hydroxy- and oxoacids (Frimer, 1979), (ii) reduction to the corresponding hydroxyacids by peroxygenases, which catalyze an intermolecular transfer of oxygen from hydroperoxides to the double bonds of fatty acids yielding alcohols and epoxides (Blée and Schubert, 1995; Blée, 1998), (iii) heterolytic proton-catalysed cleavage leading to the formation of two carbonyl fragments (Hock cleavage) initiated by migration of groups to positive oxygen (Frimer, 1979), and (iv) isomerization to allylic 1,4-diols by hydroperoxide isomerases (Fig. 6). It is important to note that this last process affords erythro isomers (Jernerén et al., 2010), which are different to the threo isomers resulting from diol synthase activity.

Intermolecular transfer of oxygen from hydroperoxides to the double bond of palmitoleic acid by peroxygenases affords Z-9,10epoxyhexadecanoic acid (20) (Fig. 7; Blée and Schubert, 1995; Blée, 1998). This Z-configuration may also be produced by stereospecific Z-epoxidation of palmitoleic acid by a hydroperoxide 


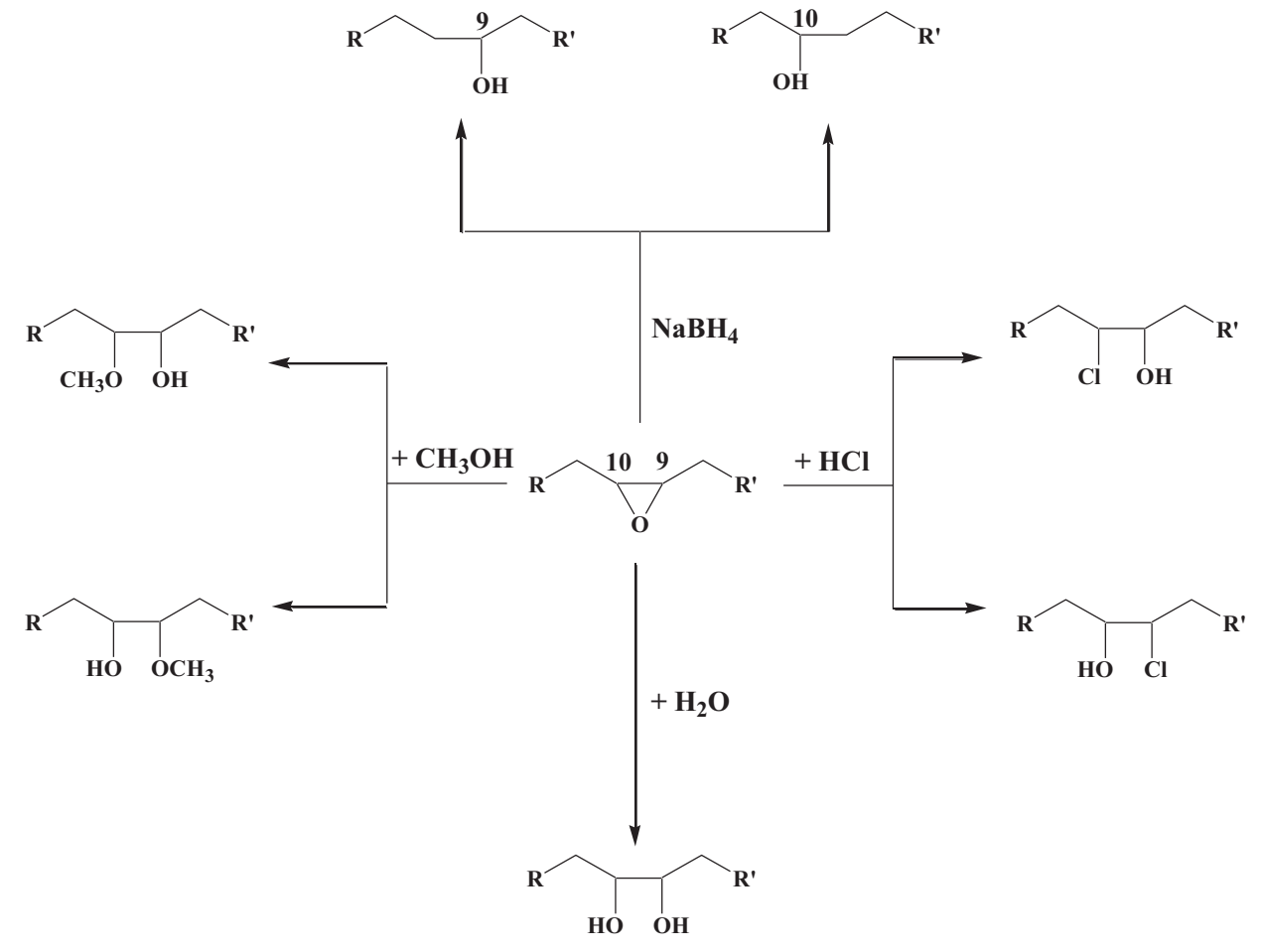

$$
\begin{aligned}
& \mathbf{R}=\mathrm{CH}_{3}-\left(\mathrm{CH}_{2}\right)_{4^{-}} \\
& \mathbf{R}^{\prime}=-\left(\mathrm{CH}_{2}\right)_{6}-\mathrm{COOH}
\end{aligned}
$$

Fig. 2. Degradation of 9,10-epoxyhexadecanoic acid during the treatment.

species in the presence of transition metal ions (Fig. 7; Hansel and Evershed, 2009). In contrast, hydroperoxyl radical addition to one end of the double bond of palmitoleic acid is not stereoselective. Indeed, in this case intramolecular homolytic substitution (Fossey et al., 1995) can occur on the resulting free radical after rotation about the position of the original double bond affording $Z$ - and $E$ epoxides (Fig. 7). Isomerization of palmitoleic acid to hexadec-9 (Z)-enoic acid (palmitelaidic acid) catalyzed by thiyl radicals (Ferreri et al., 2005), metal ions (Holtwick et al., 1997) or Z/E bacterial isomerases (Heipieper et al., 2003) and subsequent epoxidation by the three processes described above, constitute other potential sources of ( $Z$ and $E$ ) 9,10-epoxyhexadecanoic acids (20) (Fig. 7).

The higher abundance of 10-hydroxyhexadecanoic acid (14) relative to its 9 -isomer (13) (Fig. 1a) was attributed to the involvement of hydratase. Indeed, several bacteria are able to hydrate, stereospecifically, $\Delta^{9}$ double bonds of fatty acids to 10hydroxyacids (El-Sharkawy et al., 1992; Yang et al., 1993; Hou, 1994), which are often subsequently dehydrogenated by alcohol dehydrogenases to the corresponding 10-ketoacids (El-Sharkawy et al., 1992). Reduction of the samples with $\mathrm{NaBD}_{4}$ instead of $\mathrm{NaBH}_{4}$ allowed us to estimate the relative proportions of 10hydroxyhexadecanoic acid (14) and 10-oxohexadecanoic acid (35) in sea ice (9:1).

\subsection{Degradation of palmitoleic acid in sinking particles}

The dominance of Nitzschia frigida (1-20\%) and Fragilariopsis oceanica $(2-24 \%)$ (well-known diatom species in sea ice; Poulin et al., 2011; Ren et al., 2014) in the sediment trap material
(Lalande, unpublished data) confirms a sea ice origin for the majority of sinking particles. The high contribution of ice diatoms to this material is also supported by the strong dominance of palmitoleic acid in TLEs (Fahl and Kattner, 1993). Ice algae appeared to be very weakly degraded within the water column, with degradation percentages of palmitoleic acid of only $4.8 \%, 5.4 \%$, and $4.3 \%$ in ice, upper and deeper sediment traps, respectively. This relative preservation is likely attributed to the poor physiological state of bacterial communities associated with ice algae resulting from salinity stress in brine channels (Amiraux et al., 2017).

Stereospecific allylic rearrangement of 10-hydroperoxyhexadec-8(E)-enoic acid (3) to 8-hydroperoxyhexadec-9(E)-enoic acid (4), which appeared to be very limited in sea ice (Fig. 1a), acted very intensively in sinking particles (Fig. 1b). The extent of this rearrangement increased with time (Porter et al., 1995), with higher proportions of the 8-E isomer observed in sinking particles confirming the aging of the material collected in the sediment traps.

A significant increase of the proportion of 10hydroxyhexadecanoic acid (14) was observed in sinking particles (Fig. 1, Tables 1 and 3) suggesting an enhancement in the activity of hydratases within the water column. Interestingly, it was previously demonstrated that myosin cross-reactive antigen (MCRA) proteins acting as a hydratase on $9(Z)$ double bonds of fatty acids, play a role in adherence of bacteria (Volkov et al., 2010). Indeed, free unsaturated fatty acids (and notably palmitoleic acid, Wille and Kydonieus, 2003) are toxic for many bacteria due to their deleterious effect on bacterial cellular membranes (Greenway and Dyke, 1979). They also inhibit enoyl-ACP reductase and thus disrupt bacterial fatty acid synthesis (Zheng et al., 2005). Hydration 

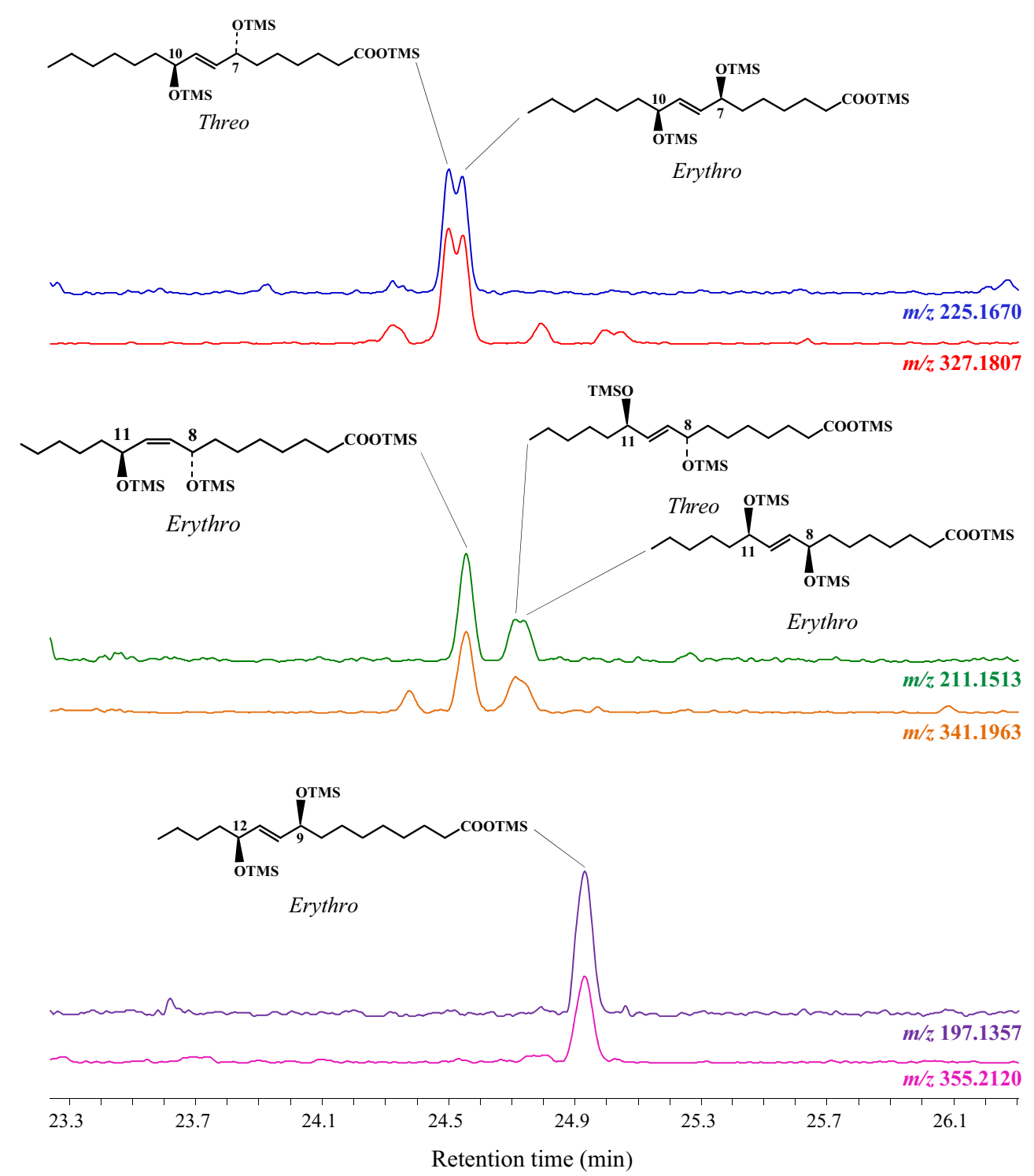

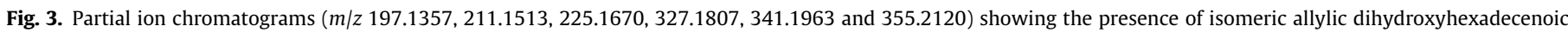
acids in superficial bottom sediments $(0-1 \mathrm{~cm})$.

of unsaturated fatty acids may thus represent a detoxification mechanism in bacteria harboring MCRA enzymes. Such detoxification could be essential for bacterial colonization and survival on free fatty acid-rich environments such as ice algae (Falk-Petersen et al., 1998). However, it may be noted that such enhancement of hydratase activity was not previously observed in sinking particles collected in spring 2012 at a landfast ice station in Resolute Passage (Nunavut, Canada) (Rontani et al., 2016), probably due to the higher aggregation state of the ice algae (Amiraux et al., 2017), resulting from an enhanced EPS content. In this case, the presence of high amounts of EPS around ice algae cells could have limited the toxicity of unsaturated fatty acids toward bacteria.

The intense $Z / E$ isomerisation of palmitoleic acid observed in the deeper sediment trap samples (Table 1) may result from the involvement of thiyl radicals. Indeed, functionalised aliphatic thiols (glutathione, methionine-containing proteins), which are present in living organisms in considerable amounts (Ferreri et al.,
2005), are extraordinarily efficient antioxidants that protect the cells against consequences of damage induced by free radicals and hydroperoxides (Wlodek, 2002). However, this role as repairing agents is counterbalanced by the formation of thiyl radicals, which are efficient catalysts for $Z / E$ isomerisation of lipids in biological membranes (Ferreri et al., 2005). Due to the presence of significant amounts of hydroperoxyacids in sinking particles (Table 1 ), an induction of $Z / E$ isomerisation of palmitoleic acid by thiyl radicals resulting from the reaction of thiols with these compounds is therefore possible. However, the involvement of such an isomerisation process is not supported by the very low $E / Z$ ratios of unsaturated fatty acids measured previously in highly photooxidized sinking particles (with very high hydroperoxide contents) collected in spring 2012 at a landfast ice station in Resolute Passage (Nunavut, Canada) (Rontani et al., 2016).

Bacterial enzymatic reactions with unsaturated fatty acids constitutes another possibility to explain $Z / E$ isomerisation (Heipieper 


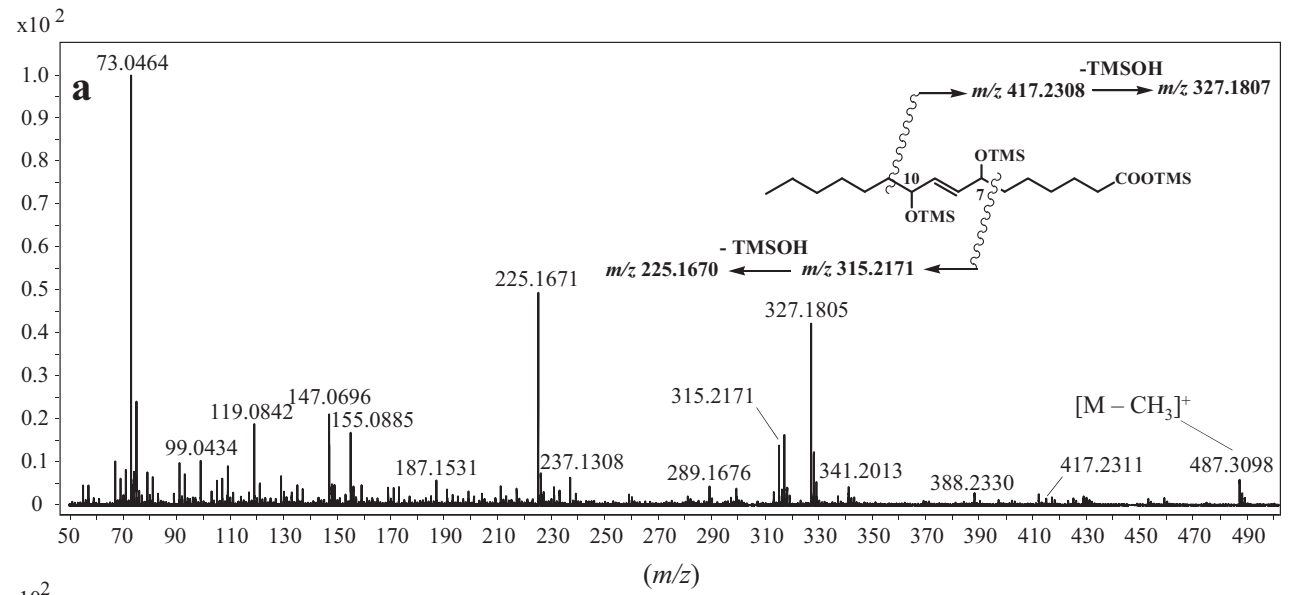

$\times 10^{2}$
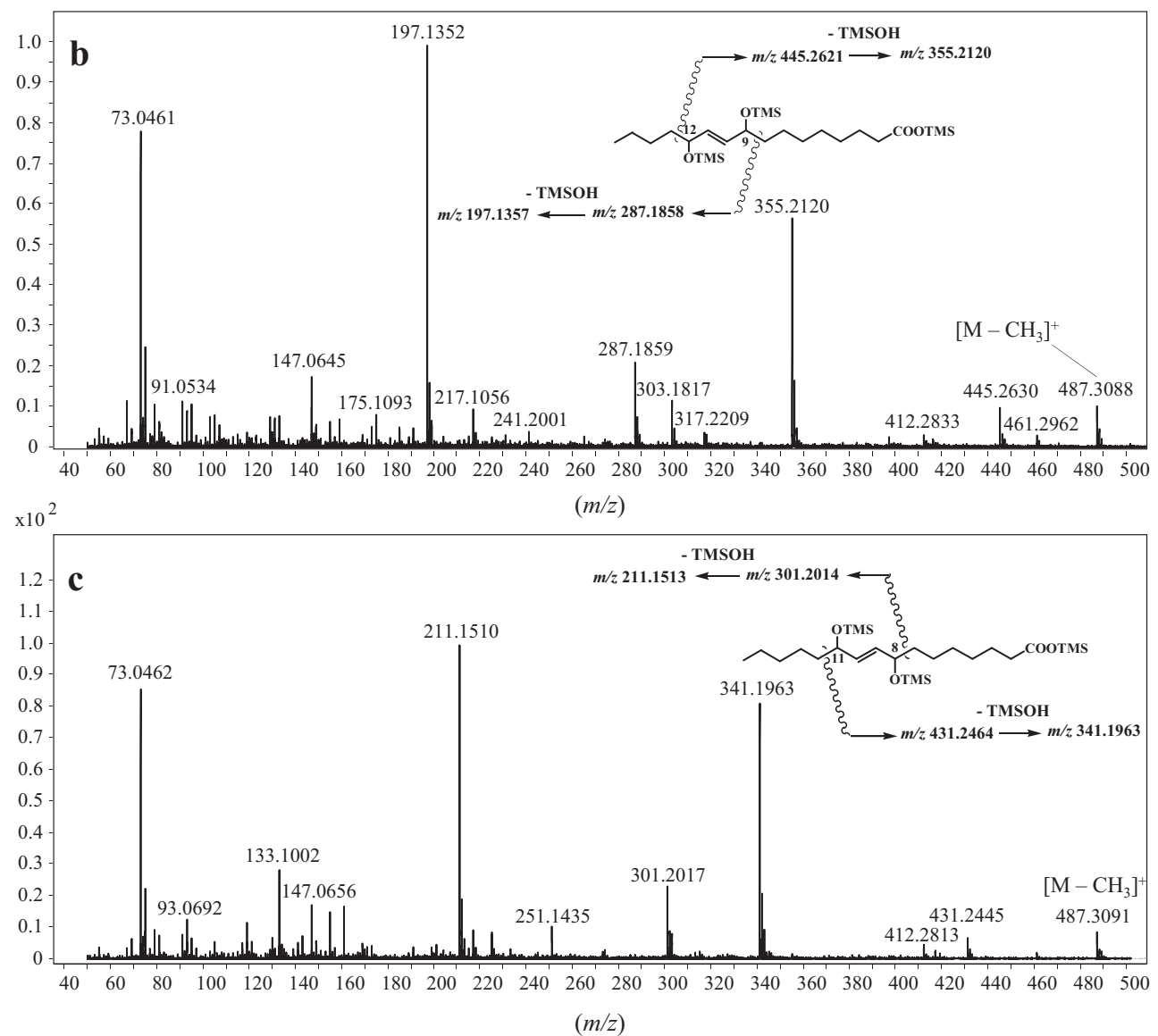

Fig. 4. TOF MS mass spectra of: 7,10-dihydroxyhexadec-8(E)-enoic (a), 9,12-dihydroxyhexadec-10(E)-enoic (b) and 8,11-dihydroxyhexadec-9(E)-enoic (c) acid trimethylsilyl ether derivatives.

et al., 2003, 2007) (Fig. 5). Such an adaptive mechanism appears to be an alternative way to regulate membrane fluidity when the growth of bacteria is inhibited by toxic compounds or environmental stress (such as high salinity; Heipieper et al., 2003). The strong isomerization of vaccenic acid observed previously in the sinking particles investigated herein was thus attributed to salinityinduced bacterial stress in brine channels during the early stages of ice melting (Amiraux et al., 2017). However, it is generally con- sidered that bacterial $Z / E$ isomerase is the only enzymatic system known to alter the double bond stereochemistry of phospholipids, whereas such enzymatic isomerisation is unknown for eukaryotes (Ferreri et al., 2005). Consequently, enzymatic isomerisation of palmitoleic acid (arising mainly from algal material in sinking particles) cannot be occurring in ice algae. Moreover, due to the location of the $Z / E$ bacterial isomerase in the periplasm and its hydrophilic properties (Heipieper et al., 2003, 2007), an activity 


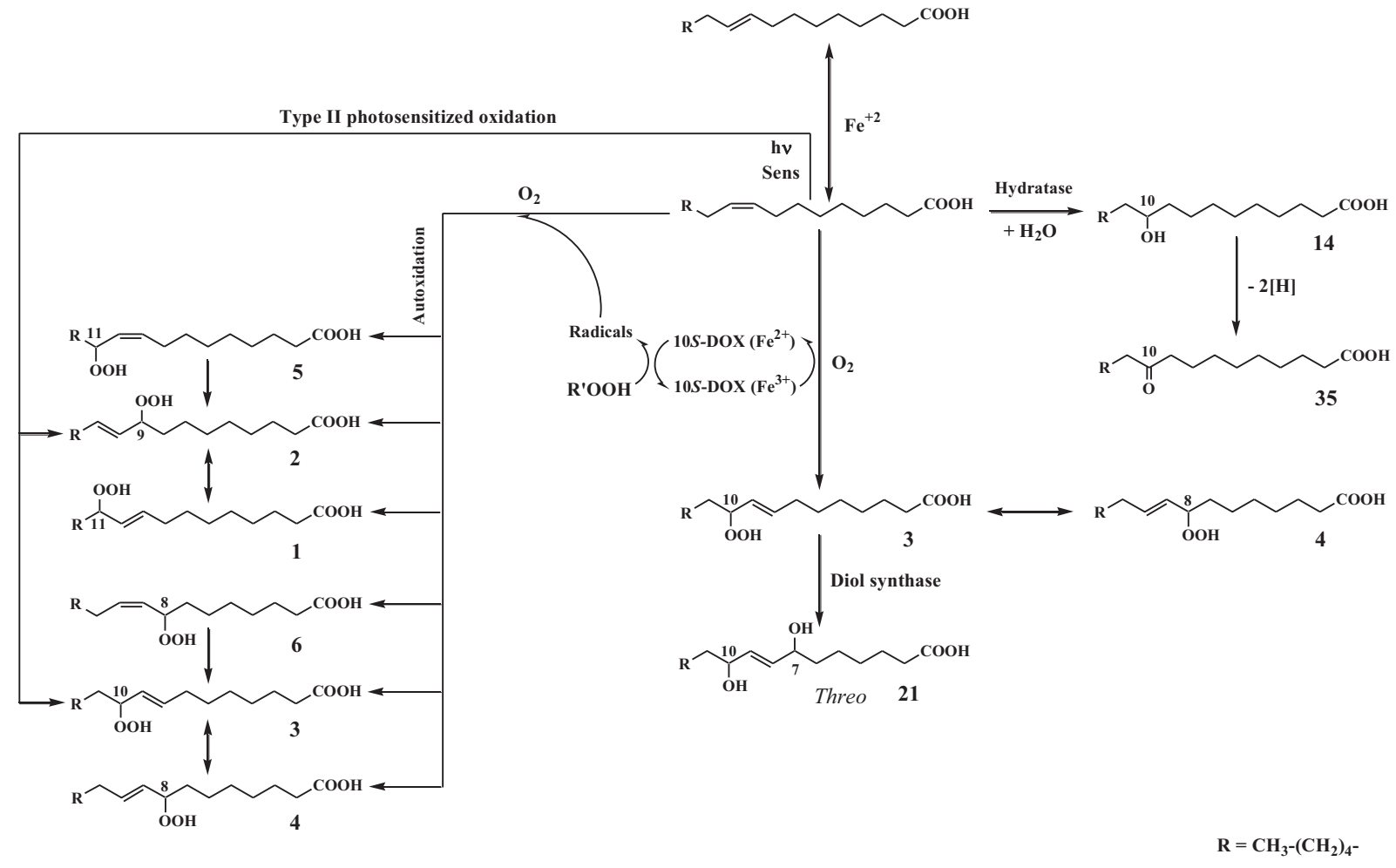

Fig. 5. Proposed biotic and abiotic degradation pathways of palmitoleic acid.

Table 2

Substrate specificity of diol synthase.

\begin{tabular}{|c|c|c|c|}
\hline Substrate & $\begin{array}{l}\text { Diol synthase } \\
\text { activity }\end{array}$ & Product & Diol formation \\
\hline 10-Hydroperoxyhexadec-8(E)-enoic acid ${ }^{\mathrm{c}}(\mathbf{3})$ & + & Threo 7,10-dihydroxyhexadec-8(E)-enoic acid (21) & Between the peroxyl and the carboxyl groups \\
\hline 9-Hydroperoxyhexadec-10(E)-enoic acid ${ }^{\mathrm{C}}(\mathbf{2})$ & - & Threo 9,12-dihydroxyhexadec-10(E)-enoic acid $(\mathbf{2 4})$ & Between the peroxyl and the methyl groups \\
\hline 8-Hydroperoxyhexadec-9(E)-enoic acid ${ }^{\mathrm{c}}(\mathbf{4})$ & $t^{\mathrm{a}}$ & Threo 8,11-dihydroxyhexadec-9(E)-enoic acid (22) & Between the peroxyl and the methyl groups \\
\hline 8-Hydroperoxyhexadec-9(Z)-enoic acid ${ }^{\mathrm{C}}(\mathbf{6})$ & - & Threo 8,11-dihydroxyhexadec-9(Z)-enoic acid (23) & Between the peroxyl and the methyl groups \\
\hline 11-Hydroperoxyhexadec-9(E)-enoic acid ${ }^{\mathrm{C}}(\mathbf{1})$ & $t^{\mathrm{a}}$ & Threo 8,11-dihydroxyhexadec-9(E)-enoic acid $(\mathbf{2 2})$ & Between the peroxyl and the carboxyl groups \\
\hline 11-Hydroperoxyhexadec-9(Z)-enoic acid ${ }^{\mathrm{c}}(\mathbf{5})$ & - & Threo 8,11-dihydroxyhexadec-9(Z)-enoic acid (23) & Between the peroxyl and the methyl groups \\
\hline 12-Hydroperoxyoctadec-10(E)-enoic acid ${ }^{\mathrm{d}}(\mathbf{2 5})$ & + & Threo 9,12-dihydroxyoctadec-10(E)-enoic acid (31) & Between the peroxyl and the carboxyl groups \\
\hline 11-Hydroperoxyoctadec-12(E)-enoic acid ${ }^{\mathrm{d}}(\mathbf{2 6})$ & - & Threo 11,14-dihydroxyoctadec-12(E)-enoic acid (32) & Between the peroxyl and the methyl groups \\
\hline 10-Hydroperoxyoctadec-11(E)-enoic acid ${ }^{\mathrm{d}}(\mathbf{2 7})$ & $++^{\mathrm{b}}$ & Threo 10,13 -dihydroxyoctadec-11(E)-enoic acid (33) & Between the peroxyl and the methyl groups \\
\hline 10-Hydroperoxyoctadec-11(Z)-enoic acid ${ }^{\mathrm{d}}(\mathbf{2 8})$ & - & Threo 10,13-dihydroxyoctadec-11(Z)-enoic acid (34) & Between the peroxyl and the methyl groups \\
\hline 13-Hydroperoxyoctadec-11(E)-enoic acid ${ }^{\mathrm{d}}(\mathbf{2 9})$ & $++^{\mathrm{b}}$ & Threo 10,13-dihydroxyoctadec-11(E)-enoic acid (33) & Between the peroxyl and the carboxyl groups \\
\hline 13-Hydroperoxyoctadec-11(Z)-enoic acid ${ }^{\mathrm{d}}(\mathbf{3 0})$ & - & Threo 10,13-dihydroxyoctadec-11(Z)-enoic acid (34) & Between the peroxyl and the methyl groups \\
\hline
\end{tabular}

a Source of the diol not defined (from 8- or 11-hydroperoxide?)

b Source of the diol not defined (from 10- or 13-hydroperoxide?).

c Palmitoleic oxidation products.

d Vaccenic acid oxidation products.

Table 3

Relative importance (\%) of degradation processes of palmitoleic acid in sea ice, sinking particle and surficial bottom sediment samples collected in Davis Strait.

\begin{tabular}{|c|c|c|c|c|}
\hline Degradation processes & $\begin{array}{l}\text { Sea ice } \\
(0-1 \mathrm{~cm})\end{array}$ & $\begin{array}{l}\text { Sinking particles } \\
\text { (trap } 2 \mathrm{~m} \text { ) }\end{array}$ & $\begin{array}{l}\text { Sinking particles } \\
\text { (trap } 25 \mathrm{~m} \text { ) }\end{array}$ & $\begin{array}{l}\text { Surface sediment } \\
(0-1 \mathrm{~cm})\end{array}$ \\
\hline Autoxidation & 12.3 & 5.7 & 9.3 & 19.2 \\
\hline Photooxidation & 9.3 & 4.2 & 1.4 & 19.9 \\
\hline Enzymatic $10 S$-DOX oxidation & 47.6 & 52.1 & 48.0 & 13.2 \\
\hline Enzymatic hydration & 4.9 & 15.5 & 20.0 & 8.6 \\
\hline Epoxidation (peroxygenase and autoxidation) & 25.9 & 22.5 & 21.3 & 39.1 \\
\hline
\end{tabular}




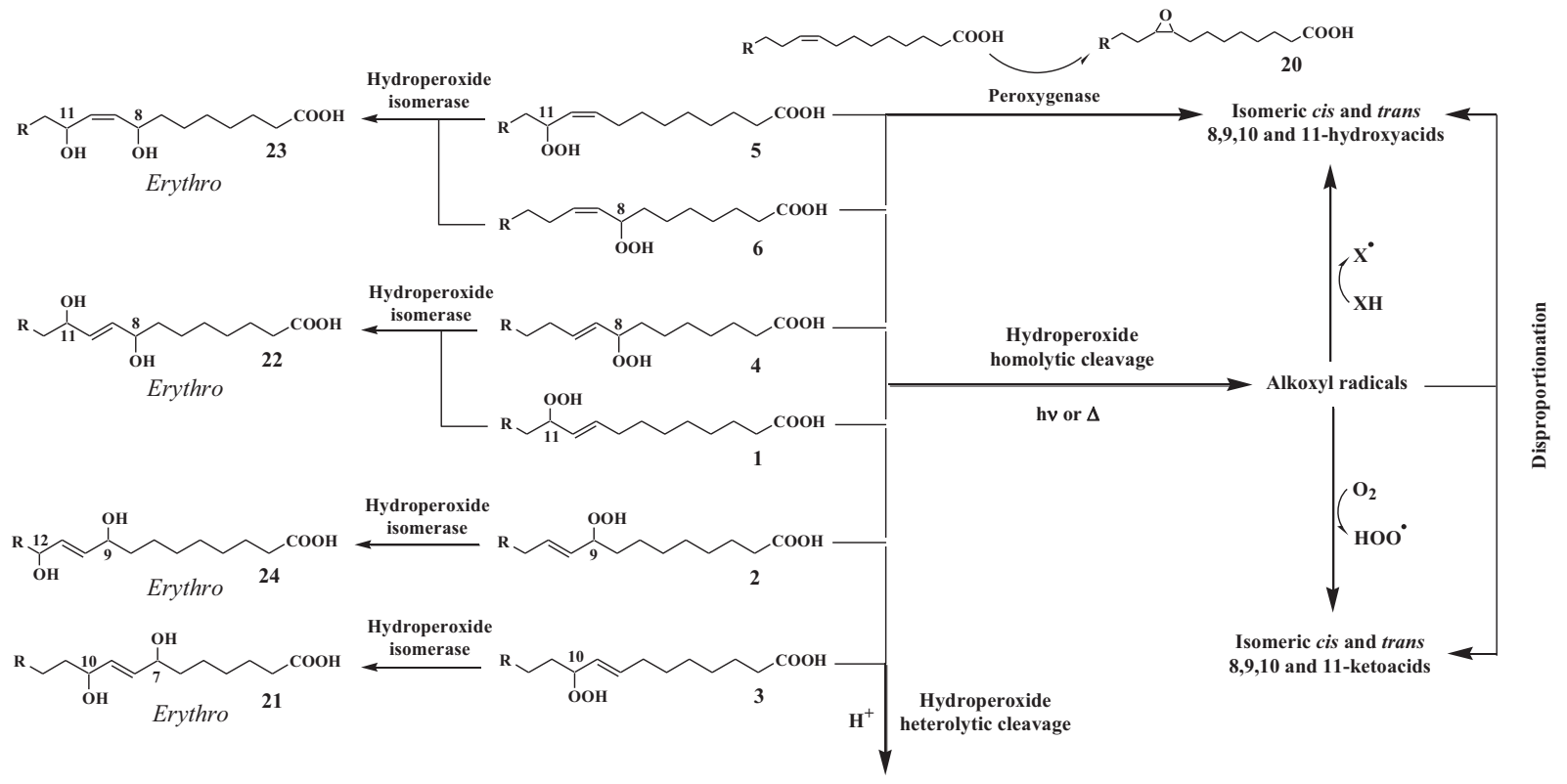

Shorter acids and $\omega$-oxoacids

$\mathbf{R}=\mathrm{CH}_{3}-\left(\mathrm{CH}_{2}\right)^{-}$

$\mathrm{X}=$ Hydrogen donnor

Fig. 6. Proposed degradation pathways of isomeric hydroperoxyhexadecenoic acids.

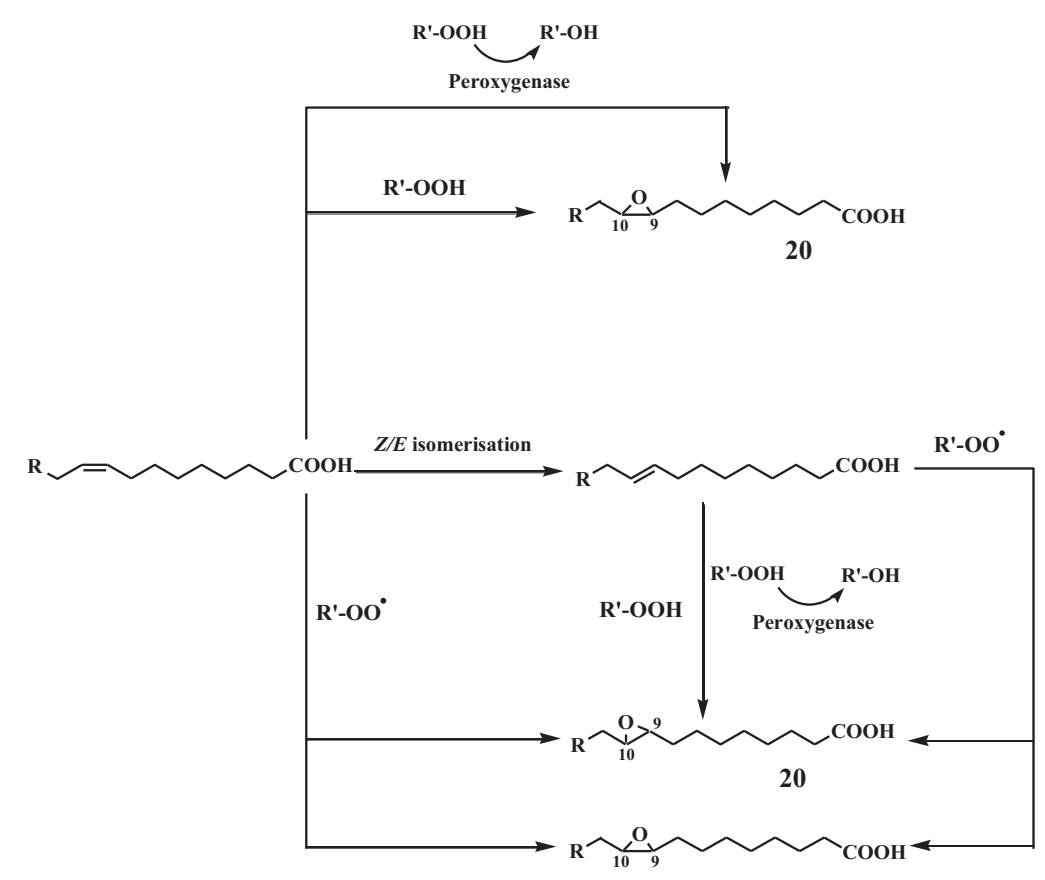

20

$\mathrm{R}=\mathrm{CH}_{3}-\left(\mathrm{CH}_{2}\right)_{4}^{-}$

Fig. 7. Proposed formation pathways of $Z$ - and E-9,10-epoxyhexadecanoic acids.

of this enzyme on palmitoleic acid in diatoms to which the bacteria are attached, is very unlikely, even in the case of lysis of both organisms.
It may be noted that $Z / E$ isomerisation of unsaturated fatty acids can also be catalyzed non-enzymatically by $\mathrm{Fe}^{2+}$ ions (Holtwick et al., 1997; Li and Han, 2008). The potential release of $\mathrm{Fe}^{2+}$ ions 
during radical-induced damage of the active site of the bacterial 10S-DOX-like lipoxygenase (Fuch and Spiteller, 2014) and Z/E isomerase (a cytochrome $C$-type protein containing an ion $\mathrm{Fe}^{2+}$, Holtwick et al., 1997) could thus be at the origin of the $Z / E$ isomerisation of palmitoleic acid in diatoms (Fig. 5).

\subsection{Degradation of palmitoleic acid in superficial bottom sediments from north of Davis Strait}

The dominance of 10-hydroxyhexadec-8(E)-enoic acid (9) (arising from 10S-DOX-like lipoxygenase activity) among palmitoleic acid oxidation products observed in the sediments investigated (Fig. 1c) was also previously detected in several surficial sediments collected in different zones of Arctic (Amiraux, 2017). It may be attributed to a strong contribution of ice-derived OM released to Arctic sediments during the first stage of ice melting and containing bacteria stressed by salinity. It is well known that the generation of radicals in the course of the lipoxygenase catalytic cycle can act as a catalyst in autoxidation processes (Fuch and Spiteller, 2014). Moreover, when lipoxygenase activity becomes very high, increasing amounts of free radicals may damage the active site of these enzymes and release $\mathrm{Fe}^{2+}$ ions (Sato et al., 1992; Fuch and Spiteller, 2014), which may very efficiently catalyze the reduction of hydroperoxides to alkoxyl radicals (Schaich, 2005) and thereby induce free radical oxidation chains. The increase of autoxidation observed in surface sediments (Table 3 ) is thus likely initiated by the 10S-DOX-like lipoxygenase activity present in sinking ice algae (Amiraux et al., 2017).

In contrast, these sediments exhibit a higher proportion of photooxidation products of palmitoleic acid than the particles settling during the early stages of ice melting (Table 3), suggesting the contribution of an additional source of highly photooxidized sinking material. Photooxidative damage is strongly dependent on the physiological state of phototrophic cells (Nelson, 1993; Merzlyak and Hendry, 1994). At the end of the ice melt process, downward percolation of melt water strongly reduces the overall salinity in brine channels, affecting the physiological state of ice algae and increasing their susceptibility towards photooxidation (Amiraux et al., 2017). A weak contribution of highly aggregated ice algae settling during the end of ice melting, where palmitoleic photooxidation percentage was very high (mean value at $30 \mathrm{~m}$ : 60\%; Rontani et al., 2016) could thus explain the relatively high photooxidation state of palmitoleic acid observed in these sediments. It was previously observed that strands of the under-ice diatom Melosira arctica, which can cover up to $40-80 \%$ of the underside of undisturbed ice floes (Syvertsen, 1991; Gutt, 1995) and contain a high proportion of palmitoleic acid (Falk-Petersen et al., 1998), are not used as food in the pelagic zone and sink rapidly to the seafloor (Boetius et al., 2013). A contribution of strongly photooxidized $M$. arctica could thus also explain the high photooxidation state of sedimentary palmitoleic acid. However, the high chlorophyll content measured in these algal deposits (Boetius et al., 2013) (attesting to their very weak photooxidation state) allows us to discard a significant contribution of this algal material to the superficial bottom sediments analyzed. Despite its lower aggregation and thus sedimentation rate, a weak contribution of open water phytoplankton, which is strongly affected by photooxidation processes in summer in the Arctic (Rontani et al., 2012), cannot be totally excluded.

The relatively similar palmitelaidic acid/palmitoleic acid ratios observed in superficial bottom sediments and in the deeper sediment trap dominated by sympagic algae (Table 1) confirms the strong contribution of sea ice-derived OM to bottom sediments, a conclusion consistent with that derived following a previous analysis of vaccenic acid isomerisation in these samples (Amiraux et al., 2017).

\section{Conclusions}

In the present work, we detected an intense 10S-DOX-like lipoxygenase activity in sea ice, attributed to the involvement of a specific bacterial enzymatic process under the hypersaline conditions found in brine channels during the first stages of ice melting. This enzymatic activity, well-known to produce radicals, is probably at the origin of the strong autoxidation of ice algal material observed in the underlying sediments.

In the water column, the degradation of ice algal material appeared to be very limited, probably due to the presence of bacteria stressed by salinity in the overlying sea ice or by the high free fatty acid content of ice algae. The degradation of hydroperoxides (arising from 10S-DOX-like lipoxygenase oxidation, photo- and autoxidation in ice) involves peroxygenases, diol synthases, hydroperoxide isomerases and abiotic processes (homolytic and heterolytic cleavages, allylic rearrangement). The increasing hydratase activity (a well-known detoxification process in bacteria) observed in sinking particles, which attests to the toxicity of free unsaturated FA of ice algae toward their attached bacteria, constitutes another explanation of the relative preservation of ice algae within the water column. $Z / E$ isomerization of palmitoleic acid was observed in the deeper trap and in surface sediments and was attributed to $\mathrm{Fe}^{2+}$ ions released during the degradation of active sites of bacterial lipoxygenases and $Z / E$ isomerases. These ions could then enhance autoxidation of ice algal material in the underlying sediments.

Comparison of the profiles of palmitoleic acid degradation products in superficial bottom sediments and in sinking particles allowed us to propose ice algae settling during the early stages of ice melting as important contributors to Arctic sediments. A weaker contribution of ice algal material, strongly photooxidized at the end of sea ice melting, also seems likely. Due to their strong aggregation and low remineralizing potential, ice algae seem to contribute more significantly than open water phytoplankton to the export of carbon to Arctic sediments.

\section{Acknowledgements}

This work was supported by the Bacstress (funded by EC2COmicrobien) and GreenEdge (funded by ANR (Contract \#111112), CNES (project \#131425), IPEV (project \#1164), CSA, Fondation Total, ArcticNet, LEFE and the French Arctic Initiative) projects. The GreenEdge project would not have been possible without the support of the Hamlet of Qikiqtarjuaq and the members of the community as well as the Inuksuit School and its principal Jacqueline Arsenault. The project was conducted under the scientific coordination of the Canada Excellence Research Chair on Remote sensing of Canada's new Arctic frontier and the CNRS \& Université Laval Takuvik Joint International laboratory (UMI3376). We especially thank C. Nozais from Université du Québec à Rimouski for providing the sediment traps, C. Aubry and T. Dezutter from Université Laval Joint International laboratory Takuvik for allowing the 2015 short term sediment trap deployment and G. Massé for the seafloor surface sediment sampling. Thanks are due to Dr. $\mathrm{H}$. J. Heipieper for helpful discussions. We also acknowledge the FEDER OCEANOMED ( $\left.\mathrm{N}^{\circ} 1166-39417\right)$ for the funding of the apparatus employed. Finally, we thank the two anonymous reviewers for their useful and constructive comments. 


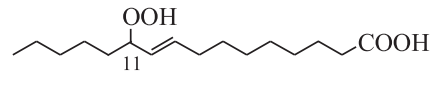

11-Hydroperoxyhexadec-9(E)-enoic acid (1)

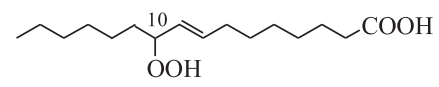

10-Hydroperoxyhexadec-8(E)-enoic acid (3)

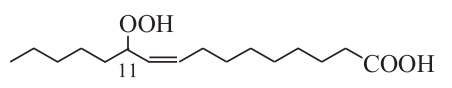

11-Hydroperoxyhexadec-9(Z)-enoic acid (5)

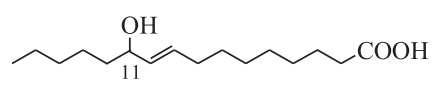

11-Hydroxyhexadec-9(E)-enoic acid (7)<smiles>CCCCCCC(O)C=CCCCCCCC(=O)O</smiles>

10-Hydroxyhexadec-8(E)-enoic acid (9)

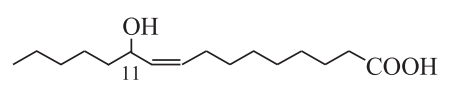

11-Hydroxyhexadec-9(Z)-enoic acid (11)

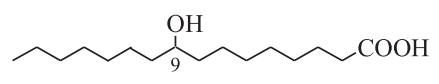

9-Hydroxyhexadecanoic acid (13)

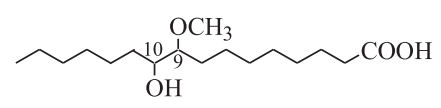

9-Methoxy-10-hydroxyhexadecanoic acid (15)

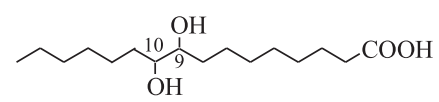

9,10-Dihydroxyhexadecanoic acid (17)<smiles>CCCCCCC(O)C(Cl)CCCCCCCCC(=O)O</smiles>

9-Chloro-10-hydroxyhexadecanoic acid (19)

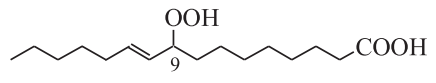

9-Hydroperoxyhexadec-10(E)-enoic acid (2)

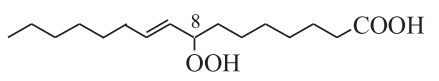

8-Hydroperoxyhexadec-9(E)-enoic acid (4)

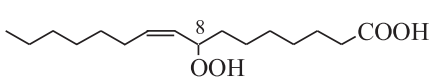

8-Hydroperoxyhexadec-9(Z)-enoic acid (6)

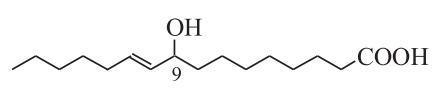

9-Hydroxyhexadec-10(E)-enoic acid (8)

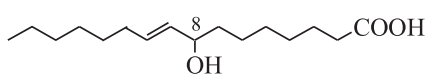

8-Hydroxyhexadec-9(E)-enoic acid (10)

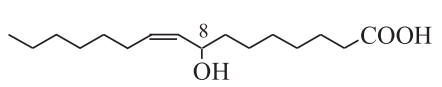

8-Hydroxyhexadec-9(Z)-enoic acid (12)

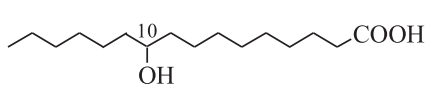

10-Hydroxyhexadecanoic acid (14)

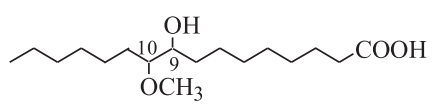

10-Methoxy-9-hydroxyhexadecanoic acid (16)

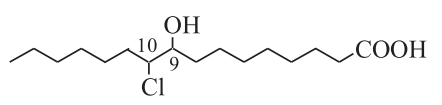

10-Chloro-9-hydroxyhexadecanoic acid (18)

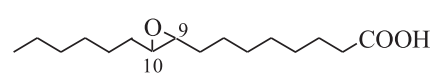

9,10-Epoxyhexadecanoic acid (20) 
<smiles>CCCCCCC(O)C=CC(O)CCCCCC(=O)O</smiles>

7,10-Dihydroxyhexadec-8(E)-enoic acid (21)<smiles>CCCCCC(O)CCCCCCCCCC(=O)O</smiles>

8,11-Dihydroxyhexadec-9(Z)-enoic acid (23)<smiles>CCCCCC[C@H](O)/C=C/CCCCCCCCC(=O)O</smiles>

12-Hydroperoxyoctadec-10(E)-enoic acid (25)<smiles>CCCCCCC=CC[C@H](O)CCCCCCCC(=O)O</smiles>
$\mathrm{OOH}$

10-Hydroperoxyoctadec-11(E)-enoic acid (27)<smiles>CCCCC[C@H](O)/C=C/CCCCCCCCCC(=O)O</smiles>

13-Hydroperoxyoctadec-11(E)-enoic acid (29)<smiles>CCCCCCC(O)C=CC(O)CCCCCCCC(=O)O</smiles>

9,12-Dihydroxyoctadec-10(E)-enoic acid (31)<smiles>CCCCCC(O)C=CC(O)CCCCCCCC(=O)O</smiles>

10,13-Dihydroxyoctadec-11(E)-enoic acid (33)<smiles>CCCCCCC(=O)CCCCCCCCC(=O)O</smiles>

10-Oxohexadecanoic acid (35)

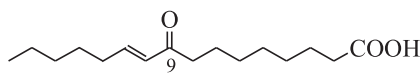

9-Oxohexadec-10(E)-enoic acid (37)<smiles>CCCCCC/C=C/C(=O)CCCCCCC(=O)O</smiles>

8-Oxohexadec-9(E)-enoic acid (39)<smiles>CCCCCCC=CCCCCCCCC(=O)O</smiles>

8-Oxohexadec-9(Z)-enoic acid (41)

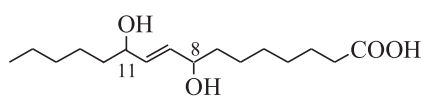

8,11-Dihydroxyhexadec-9(E)-enoic acid (22)<smiles>CCCC[C](O)C=C[C@H](O)CCCCCCCC(=O)O</smiles>

9,12-Dihydroxyhexadec-10(E)-enoic acid (24)

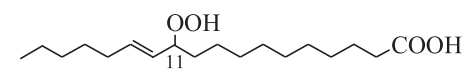

11-Hydroperoxyoctadec-12(E)-enoic acid (26)

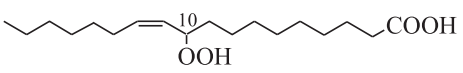

10-Hydroperoxyoctadec-11(Z)-enoic acid (28

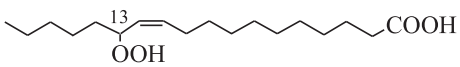

13-Hydroperoxyoctadec-11(E)-enoic acid (30)<smiles>CCCCC(O)C=CC(C)(O)CCCCCCCCC(=O)O</smiles>

11,14-Dihydroxyoctadec-12(E)-enoic acid (32)<smiles>CCCCC(O)CCCCCCCCCCCC(=O)O</smiles>

10,13-Dihydroxyoctadec-11(Z)-enoic acid (34)<smiles>CCCCCC(=O)C=CCCCCCCCC(=O)O</smiles>

11-Oxohexadec-9(E)-enoic acid (36)<smiles>CCCCCCC(=O)C=CCCCCCCC(=O)O</smiles>

10-Oxohexadec-8(E)-enoic acid (38)<smiles>CCCCCC(C)C=CCCCCCCCC(=O)O</smiles>

11-Oxohexadec-9(Z)-enoic acid (40)

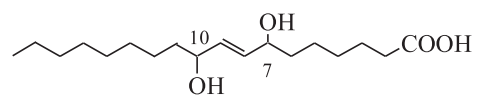

7,10-Dihydroxyoctadec-8(E)-enoic acid (42)

\section{References}

Amiraux, R., 2017. Ice biota degradation in the Arctic environment: impact of bacterial stress state on this material's preservation and burial ( $\mathrm{PhD}$ thesis). University of Aix Marseille, France.

Amiraux, R., Belt, S.T., Vaultier, F., Galindo, V., Gosselin, M., Bonin, P., Rontani, J.-F., 2017. Monitoring of photooxidative and osmotic bacterial stresses in Arctic using specific lipid tracers. Marine Chemistry 194, 89-99.

Amiraux, R., Rontani, J.-F., Armougom, F., Frouin, E., Babin, M., Artigue, L., Bonin, P., iraux et al., submitted for publication. Deciphering biodiversity and stress state of bacterial communities associated with ice algae and sinking particles in Canadian Arctic: impact to carbon flux. ISME Journal (submitted for publication).

Arzel, O., Fichefet, T., Goosse, H., 2006. Sea ice evolution over the 20th and 21st centuries as simulated by current AOGCMs. Ocean Modeling 12, 401-415.
Blée, E., Schuber, F., 1995. Oxylipins in plants: The peroxygenase pathway. In: Kader, J.-.C., Mazliak, P. (Eds.), Plant Lipid Metabolism. Kluwer Academic Publishers, Dordrecht, pp. 262-264.

Blée, E., 1998. Phytooxylipins and plant defense reactions. Progress in Lipid Research 37, 33-72.

Boetius, A., Albrecht, S., Bakker, K., Bienhold, C., Felden, J., Fernández-Méndez, M. Hendricks, S., Katlein, C., Lalande, C., Krumpen, T., Nicolaus, M., Peeken, I., Rabe, B., Rogacheva, A., Rybakova, E., Somavilla, R., Wenzhöfer, F., Polarstern, R.V. 2013. ARK27-3-Shipboard Science PartyExport of algal biomass from the melting Arctic sea ice. Science 339, 1430-1432.

Busquets, M., Deroncelé, V., Vidal-Mas, J., Rodríguez, E., Guerrero, A., Manresa, A. 2004. Isolation and characterization of a lipoxygenase from Pseudomonas 42A2 responsible for the biotransformation of oleic acid into (S)-(E)-10-hydroxy-8octadecenoic acid. Antonie Van Leeuwenhoek 85, 129-139.

Carroll, M.L., Carroll, J., 2003. The Arctic seas. In: Black, K., Shimmield, G. (Eds.), Biogeochemistry of Marine Systems. Blackwell Publishing Ltd., Oxford, UK, pp. $127-156$.

De Carvalho, C.C.C.R., Caramujo, M.-J., 2014. Fatty acids as a tool to understand microbial diversity and their role in food webs of Mediterranean temporary ponds. Molecules 19, 5570-5598. 
El-Sharkawy, S.H., Yang, W., Dostal, L., Rosazza, J.P.N., 1992. Microbial oxidation of oleic acid. Applied and Environmental Microbiology 58, 2116-2122.

Estupiñán, M., Diaz, P., Manresa, A., 2014. Unveiling the genes responsible for the unique Pseudomonas aeruginosa oleate-diol synthase activity. Biochimica et Biophysica Acta - Molecular and Cell Biology of Lipids 1841, 1360-1371.

Estupiñán, M., Álvarez-García, D., Barril, X., Diaz, P., Manresa, A., 2015. In silico/ in vivo insights into the functional and evolutionary pathway of Pseudomonas aeruginosa oleate-diol synthase. Discovery of a new bacterial di-heme cytochrome C peroxidase subfamily. PLoS One. https://doi.org/10.1371/ journal.pone.0131462.

Fahl, K., Kattner, G., 1993. Lipid content and fatty acid composition of algal communities in sea-ice and water from the Weddell Sea (Antarctica). Polar Biology 13, 405-409.

Falk-Petersen, S., Sargent, J.R., Henderson, J., Hegseth, E.N., Hop, H., Okolodkov, Y.B. 1998. Lipids and fatty acids in ice algae and phytoplankton from the Marginal Ice Zone in the Barents Sea. Polar Biology 20, 41-47.

Ferreri, C., Kratzsch, S., Landi, L., Brede, O., 2005. Thiyl radicals in biosystems: effects on lipid structures and metabolisms. Cellular and Molecular Life Sciences 62, 834-847.

Fortier, M., Fortier, L., Michel, C., Legendre, L., 2002. Climatic and biological forcing of the vertical flux of biogenic particles under seasonal Arctic sea ice. Marine Ecology Progress Series 225, 1-16.

Fossey, J., Lefort, D., Sorba, J., 1995. Free Radicals in Organic Chemistry. Masson, Paris.

Frankel, E.N., 1998. Lipid Oxidation. The Oily Press, Dundee, Scotland.

Frimer, A.A., 1979. The reaction of singlet oxygen with olefins: the question of mechanism. Chemical Review 79, 359-387.

Fuchs, C., Spiteller, G., 2014. Iron release from the active site of lipoxygenase Zeitschrift für Naturforschung C 55, 643-648.

Galeron, M.-A., Radakovitch, O., Charriere, B., Vaultier, F., Volkman, J.K., Bianchi, T.S. Ward, N.T., Medeiros, P., Sawakuchi, H., Tank, S., Kerhervé, P., Rontani, J.-F. 2018. Lipoxygenase-induced autoxidative degradation of terrestrial particulate organic matter in estuaries: a widespread process enhanced at high and low latitudes. Organic Geochemistry 115, 78-92.

Garreta, A., Val-Moraes, S.P., Garcia-Fernandez, Q., Busquets, M., Juan, C., Oliver, A. Ortiz, A., Gaffney, B.J., Fita, I., Manresa, A., Carpena, X., 2013. Structure an interaction with phospholipids of a prokaryotic lipoxygenase from Pseudomonas aeruginosa. The FASEB Journal, 1-11.

Greenway, D.L.A., Dyke, K.G.H., 1979. Mechanism of the inhibitory action of linoleic acid on the growth of Staphylococcus aureus. Journal of General Microbiology $115,233-245$.

Guerrero, A., Casals, I., Busquets, M., Leon, Y., Manresa, A., 1997. Oxidation of oleic acid to (E)-10-hydroperoxy-8-octadecenoic and (E)-10-hydroxy-8-octadecenoic acids by Pseudomonas sp. 42A2. Biochimica et Biophysica Acta - Lipids and Lipid Metabolism 1347, 75-81.

Gutt, J., 1995. The occurrence of sub-ice algae aggregations off northeast Greenland. Polar Biology 15, 247-252.

Hansel, F.A., Evershed, R.P., 2009. Formation of dihydroxy acids from Zmonounsaturated alkenoic acids and their use as biomarkers for the processing of marine commodities in archaeological pottery vessels Tetrahedron Letters 50, 5562-5564.

Heipieper, H.J., Meinhardt, F., Segura, A., 2003. The cis-trans isomerase of unsaturated fatty acids in Pseudomonas and Vibrio: biochemistry, molecular biology and physiological function of a unique stress adaptive mechanism. FEMS Microbiology Letters 229, 1-7.

Heipieper, H.J., Neumann, G., Cornelissen, S., Meinhardt, F., 2007. Solvent-tolerant bacteria for biotransformations in two-phase fermentation systems. Applied Microbiology and Biotechnology 74, 961-973.

Holtwick, R., Meinhardt, F., Keweloh, H., 1997. Cis-trans isomerization of unsaturated fatty acids: Cloning and sequencing of the cti gene from Pseudomonas putida P8. Applied and Environmental Microbiology 63, 42924297.

Hou, C.T., 1994. Production of 10-ketastearic acid from oleic acid by Flavobacterium sp. strain DS5 (NRRL B-14859). Applied and Environmental Microbiology 60 3760-3763.

Jernerèn, F., Garscha, U., Hoffmann, I., Hamberg, M., Oliw, E.H., 2010. Reaction mechanism of 5,8-linoleate diol synthase, 10R-dioxygenase and 8,11hydroperoxide isomerase of Aspergillus clavatus. Biochimica et Biophysica Acta 1801, 503-507.

Knothe, G., Bagby, M.O., Weisleder, D., Peterson, R.E., 1994. Allylic mono- and dihydroxylation of isolated double bonds with selenium dioxide-tert-butyl hydroperoxide. NMR characterization of long-chain enols, allylic and saturated 1,4-diols, and enones. Journal of the Chemical Society - Perkin Transactions, 1661-1669.

Krembs, C., Engel, A., 2001. Abundance and variability of microorganisms and transparent exopolymer particles across the ice-water interface of melting first-year sea ice in the Laptev Sea (Arctic). Marine Biology 138, 173-185.

Leu, E., Wiktor, J., Soreide, J.E., Berge, J., Falk-Petersen, S., 2010. Increased irradiance reduces food quality of sea ice algae. Marine Ecology Progress Series 411, 49-60.

Li, X.-X., Han, L.-H., 2008. Iron(II)-induced isomerization of (all-E)-xanthophyll pigments lutein, zeaxanthin and $\beta$-cryptoxanthin in acetone. European Food Research and Technology 227, 1307-1313.

Lizotte, M.P., 2001. The contributions of sea ice algae to Antarctic marine primary production. American Zoologist 41, 57-73.

Loidl-Stahlhofen, A., Spiteller, G., 1994. $\alpha$-Hydroxyaldehydes, products of lipid peroxidation. Biochimica et Biophysica Acta 1211, 156-160.
McCloskey, J.A., McClelland, M.J., 1965. Mass spectra of O-isopropylidene derivatives of unsaturated fatty esters. Journal of the American Chemical Society 87, 5090-5093.

McMahon, K.W., Ambrose Jr., W.G., Johnson, B.J., Sun, M.-Y., Lopez, G.R., Clough, L. M., Carroll, M.L., 2006. Benthic community response to ice algae and phytoplankton in Ny Ålesund, Svalbard. Marine Ecology Progress Series 310, $1-14$.

Marchand, D., Rontani, J.-F., 2001. Characterisation of photooxidation and autoxidation products of phytoplanktonic monounsaturated fatty acids in marine particulate matter and recent sediments. Organic Geochemistry 32, 287-304.

Marchand, D., Rontani, J.-F., 2003. Visible light-induced oxidation of lipid components of purple sulfur bacteria: a significant process in microbial mats. Organic Geochemistry 34, 61-79.

Meiners, K., Gradinger, R., Fehling, J., Civitarese, G., Spindler, M., 2003. Vertical distribution of exopolymer particles in sea ice of the Fram Strait (Arctic) during autumn. Marine Ecology Progress Series 248, 1-13.

Merzlyak, M.N., Hendry, G.A.F., 1994. Free radical metabolism, pigment degradation and lipid peroxidation in leaves during senescence. Proceedings of the Royal Society of Edinburgh, Section B: Biological Sciences 102, 459-471.

Michel, C., Legendre, L., Ingram, R.G., Gosselin, M., Levasseur, M., 1996. Carbon budget of sea-ice algae in spring: evidence of a significant transfer to zooplankton grazers. Journal of Geophysical Research 101, 18345-18360.

Mihara, S., Tateba, H., 1986. Photosensitized oxygenation reactions of phytol and its derivatives. Journal of Organic Chemistry 51, 1142-1144.

Nelson, J.R., 1993. Rates and possible mechanism of light-dependent degradation of pigments in detritus derived from phytoplankton. Journal of Marine Research $51,155-179$.

Oliver, J.O., Colwell, R., 1973. Extractable lipids of gram-negative marine bacteria: Fatty acid composition. International Journal of Systematic Bacteriology 23, $442-458$.

Porter, N.A., Caldwell, S.E., Mills, K.A., 1995. Mechanisms of free radical oxidation of unsaturated lipids. Lipids 30, 277-290.

Poulin, M., Daugbjerg, N., Gradinger, R., Ilyash, L., Ratkova, T., von Quillfeldt, C., 2011. The pan-Arctic biodiversity of marine pelagic and sea-ice unicellular eukaryotes: a first-attempt assessment. Marine Biodiversity 41, 13-28.

Ren, J., Gersonde, R., Esper, O., Sancetta, C., 2014. Diatom distributions in northern North Pacific surface sediments and their relationship to modern environmental variables. Palaeogeography Palaeoclimatology and Palaeoecology 402, 81-103.

Renaud, P.E., Morata, N., Ambrose Jr., W.G., Bowie, J.J., Chiuchiolo, A., 2007. Carbon cycling by seafloor communities on the eastern Beaufort Sea shelf. Journal of Experimental Marine Biology and Ecology 349, 248-260.

Riebesell, U., Schloss, I., Smetacek, V., 1991. Aggregation of algae released from melting sea ice-implications for seeding and sedimentation. Polar Biology 11, $239-248$.

Rontani, J.-F., 2012. Photo- and free radical-mediated oxidation of lipid components during the senescence of phototrophic organisms. In: Nagata, T. (Ed.), Senescence. Intech, Rijeka, pp. 3-31.

Rontani, J.-F., Charriere, B., Forest, A., Heussner, S., Vaultier, F., Petit, M., Delsaut, N., Fortier, L., Sempéré, R., 2012. Intense photooxidative degradation of planktonic and bacterial lipids in sinking particles collected with sediment traps across the Canadian Beaufort Shelf (Arctic Ocean). Biogeosciences 9, 4787-4802.

Rontani, J.-F., Belt, S.T., Brown, T.A., Amiraux, R., Gosselin, M., Vaultier, F., Mundy, C. J., 2016. Monitoring abiotic degradation in sinking versus suspended Arctic sea ice algae during a spring ice melt using specific lipid oxidation tracers. Organic Geochemistry 98, 82-97.

Saliot, A., Parrish, C.C., Sadouni, N., Bouloubassi, L., Fillaux, J., Cauwet, G., 2002. Transport and fate of Danube Delta terrestrial organic matter in the Northwest Black Sea mixing zone. Marine Chemistry 79, 243-259.

Sato, K., Akaike, T., Kohno, M., Ando, M., Maeda, H., 1992. Hydroxyl radical production by $\mathrm{H}_{2} \mathrm{O}_{2}$ plus $\mathrm{Cu}, \mathrm{Zn}$-superoxide dismutase reflects the activity of free copper released from the oxidatively damaged enzyme. Journal of the Biological Chemistry 267, 25371-25377.

Schaich, K.M., 2005. Lipid oxidation: Theoretical aspects. In: Shahidi, F. (Ed.), Bailey's Industrial Oil and Fat Products. John Wiley \& Sons, Chichester, pp. 269355.

Suh, M.-J., Baek, K.-Y., Kim, B.-S., Hou, C.T., Kim, H.R., 2011. Production of 7,10dihydroxy-8(E)-octadecenoic acid from olive oil by Pseudomonas aeruginosa PR3. Applied Microbiology Biotechnology 89, 1721-1727.

Syvertsen, E.E., 1991. Ice algae in the Barents Sea: types of assemblages, origin, fate and role in the ice edge phytoplankton bloom. Polar Research 10, 277 287.

Tedesco, M., Fettweis, X., 2012. 21st century projections of surface mass balance changes for major drainage systems of the Greenland ice sheet. Environmental Research Letters 7, 045405.

Vance, R.E., Hong, S., Gronet, K., Serhan, C., Mekalanos, J.J., 2004. The opportunistic pathogen Pseudomonas aeruginosa carries a secretable arachidonate-15lipoxygenase. Proceedings of the National Academy of Sciences of the USA $101,2135-2139$

Vancoppenolle, M., Meiners, K.M., Michel, C., Bopp, L., Brabant, F., Carnat, G., Delille, B., Lannuzel, D., Madec, G., Moreau, S., Tison, J.-L., van der Merwe, P., 2013. Role of sea ice in global biogeochemical cycles: emerging views and challenges. Quaternary Science Reviews 79, 207-230.

Viso, A.-C., Marty, J.-C., 1993. Fatty acids from 28 marine microalgae. Phytochemistry 34, 1521-1533. 
Volkov, A., Liavonchanka, A., Kamneva, O., Fiedler, T., Goebel, C., Kreikemeyer, B. Feussner, I., 2010. Myosin cross-reactive antigen of Streptococcus pyogenes M49 encodes a fatty acid double bond hydratase that plays a role in oleic acid detoxification and bacterial virulence. Journal of Biological Chemistry 285, 10353-10361.

Wassmann, P., Duarte, C.M., Agusti, S., Sejr, M.K., 2011. Footprints of climate change in the Arctic marine ecosystem. Global Change Biology 17, 1235-1249.

Wille, J.J., Kydonieus, A., 2003. Palmitoleic acid isomer $\left(C_{16: 146}\right)$ in human skin sebum is effective against gram-positive bacteria. Skin Pharmacology and Applied Skin Physiology 16, 176-187.

Wlodek, L., 2002. Beneficial and harmful effects of thiols. Polish Journal of Pharmacology 54, 215-223.
Yang, W., Dostal, L., Rosazza, J.P.N., 1993. Stereospecificity of microbial hydrations of oleic acid to 10-hydroxystearic acid. Applied and Environmental Microbiology 59, 281-284.

Zabeti, N., Bonin, P., Volkman, J.K., Jameson, I., Guasco, S., Rontani, J.-F., 2010 Potential alteration of $U_{37}^{K}$ paleothermometer due to selective degradation of alkenones by marine bacteria isolated from the haptophyte Emiliania huxleyi. FEMS Microbiology Ecology 73, 83-94.

Zaikin, V., Halket, J.M., 2009. A Handbook of Derivatives for Mass Spectrometry. IM Publications, Chichester, UK.

Zheng, H.Q., Rowland, O., Kunst, L., 2005. Disruptions of the Arabidopsis enoyl-CoA reductase gene reveal an essential role for very-long-chain fatty acid synthesis in cell expansion during plant morphogenesis. The Plant Cell 17, 1467-1481. 